The Fournal of Modern African Studies, 37, 2 (I 999), pp. 24I-286

Printed in the United Kingdom (C) I 999 Cambridge University Press

\title{
Explaining the 1994 genocide in Rwanda
}

\author{
Helen M. Hintjens*
}

\begin{abstract}
A BSTRACT
Any adequate account of the 1994 genocide in Rwanda must acknowledge manipulation by external forces, domestic pressures and psychological factors. Even so, the nature of the Rwandan state must be seen as absolutely central. The genocide took place under the aegis of the state, and Rwandans were the main actors involved. Both precolonial legacies and colonial policies contributed to the formation of this state, whose increasingly autocratic and unpopular government was, by the early ig9os, facing serious threats to its hold on state power, for which genocide represented a last-ditch attempt at survival. Many of the mechanisms through which genocide was prepared, implemented and justified in Rwanda bore striking resemblances to those used during the twentieth century's other major genocide, the Nazi Holocaust against the Jews.
\end{abstract}

\section{INTR O D UGTION}

By i994, Tutsi in Rwanda, much like Jews in Nazi Germany, were 'socially dead' people, whose murder was as acceptable as it became common. (Uvin I997: II3)

Understanding why they died is the best and most fitting memorial we can raise for the victims. Letting their deaths go unrecorded, or distorted by propaganda, or misunderstood through simple clichés, would in fact bring the last touch to the killers' work in completing the victims' dehumanisation. (Prunier 1995: xii)

Exactly fifty years after the discovery of the Nazi death camps, the world witnessed genocide in Rwanda. According to a logic better understood now than at the time, killing of Bahutu political opponents (the prefix ba- refers to a group of people) and all Batutsi Rwandans started immediately after Juvenal Habyarimana's aeroplane was shot down over the capital, Kigali. The president of Burundi was also killed, as he was travelling in the same plane. An estimated 5-Io per cent of Rwanda's population was then killed 'between the second week of April and the third week of May' i 994; 'one of the highest casualty

\footnotetext{
* Centre for Development Studies, School of Social Sciences and International Development,
} University of Wales Swansea, Singleton Park, Swansea SA2 8PP; h.hintjens@swansea.ac.uk 
rates of any population in history from non-natural causes' (Prunier I 995: 26 I 265). Five years later it is still much too soon to come to any definite conclusions about what brought about such a remarkable atrocity; even fifty years later, there is still no consensus emerging on how to explain the Holocaust of Jews and Gypsies during the Nazi occupation of Europe. Given how little time has elapsed, it is surprising there is not more disagreement about how to interpret the r994 genocide.

In any attempt to explain something as complex as the genocide in Rwanda, parallels with other situations of mass state murder are unavoidable. Such parallels are even desirable, if the aim is to identify the particular dynamics of genocide in a particular case, like that of Rwanda (Destexhe i 995). An overwhelmingly agrarian society such as Rwanda cannot easily be compared with the heavily industrialised Germany of the I930s, but there are none the less parallels to be drawn between these two experiences. The similarities lie mainly in the extent of ideological and military preparation prior to genocide, and in the systematic use of conspiracy theories and myths to justify covert plans for slaughter. In both cases, too, more or less pristine theories of 'racial struggle' and racial hierarchy became activated and politically charged during a period of severe economic and social stress. In Rwanda, the drop in coffee prices in the mid-Ig8os set off a period of political extremism and a search for solutions that was to lead to scapegoating and physical extermination of a large part of the total Rwandan population. Economic recession was clearly a major facilitating factor in bringing latent competition and vague murderous intentions to such organised fruition, both in Nazi Germany and some decades later in Rwanda.

In Rwanda, racialist ideologies mainly served as a mask or pseudojustification for the more fundamental goal of regime survival under conditions of sharp socioeconomic crisis and growing political opposition. By mobilising vertical social cleavages, racial and ethnic political ideologies can be particularly useful to failing regimes facing widespread opposition from within 'their own ranks'. When political democratisation was imposed on Rwanda in the early i 99os, President Habyarimana's regime responded by rallying the majority 'faithful' against a purported common racial enemy, hoping in this way to prevent regional and class divisions from finding more open political expression (Article i9 I995: 32). A redefinition of national identity along exclusively racial or ethnic lines thus became the prelude for later implementation of genocide. 
In contrast with the dearth of relevant research prior to the genocide, volumes have been written about Rwanda and the Great Lakes region since i 994. There have been many detailed accounts of exactly what happened, and some attempts to explain some of the ideological and historical causes of genocide. Typical of these are the useful accounts of Chrétien (r 995), Prunier (r 995) and Reyntjens (i 995). Three broad types of explanation can be identified from an initial review of the available literature on genocide in Rwanda. These are as follows: (i) a focus on external influences, both colonial and neo-colonial; (ii) a focus on domestic causes, including demographic factors and 'ethnic' conflict; and (iii) a psychosocial account based on the presumed social conformism and obedience of Rwandans. In the first account, R wanda is seen as particularly vulnerable to colonial and neo-colonial manipulation. In the second, the country's overpopulation and social cleavages are thought to account for the genocide. In the third, genocide in Rwanda is seen as possible because of an extreme form of the obedience that is thought to characterise all highly stratified, relatively stable societies. Elements of each kind of explanation can be found in most current accounts of the r 994 genocide.

Each type of explanation has some basis in reality, as well as some blind spots. An emphasis on external factors places responsibility for genocide elsewhere, and tends to suggest that the Rwandan state and Rwandan people were merely responding to the divisive logic of imperialist interventions and strategic withdrawals. ${ }^{1}$ Attributing genocide to domestic causes such as population pressure or ethnic loyalties again suggests that in organising and carrying out genocide, Rwandans were merely responding, almost mechanistically, to domestic pressures. The third type of account stresses the dynamics of obedience and control in the Rwandan social setting, and suggests that social conformism may be so marked that even genocidal ideologies may be internalised through obedience, rather than through terror alone. This tends to reduce the Rwandan experience to a specific and extreme example of the supposed general human tendency to obey those in positions of power. All three types of explanations draw inferences for the Rwanda case from general, and usually highly contested, principles and theories. On their own, such accounts are not able to offer new insights into the particular meaning and significance of the Rwanda genocide of i 994 .

The aim of this article is to elaborate a more complex understanding of the causes of the genocide, which recognises the central role played by the regime in power, and by Rwandan people themselves. Any 
adequate account of the I994 genocide does have to acknowledge manipulation by external forces, domestic pressures and psychological factors such as obedience. But the nature of the Rwandan state must be seen as absolutely central. However externally influenced or motivated by atavistic loyalties, however obedient to outside forces, the genocide took place under the aegis of the Rwandan state, and Rwandan subjects and citizens were the main actors in the genocide (Mamdani I996). A range of public and private institutions were responsible for the critical task of planning the genocide in advance, and for ensuring its subsequent implementation through the participation of most Rwandan people, resulting in the victimisation of a significant minority.

This article first examines the legacy of colonial policies, before treating the genocide as a response to economic and political crisis in the early ig9os. A particularly lethal combination of obfuscation, terror and victim blaming is identified as having facilitated genocide in the particular case of Rwanda. Towards the end of the article, the r 994 Rwandan genocide is set in the context of relations with neighbouring Burundi. The longer-term legacy of genocide for the Great Lakes region is not assessed in detail, as it is beyond the scope of this study, and has been attempted elsewhere (Runtinwa i996; Anacleti r996; Pottier i 996).

\section{UNDERSTANDING WHY THEY DIED}

My own concern with Rwanda dates from the early ig8os, when my father received a diplomatic posting in Kigali. This made it possible to visit most parts of the country and observe at first hand what was then regarded (rightly or wrongly) as an outstanding example of orderly, well-organised and honestly administered development (see e.g. Newbury i 992). I had also lived in Tanzania and Kenya, and visited Burundi and Angola. By comparison, Rwanda in the mid-ig8os gave an impression of extreme orderliness; this was the 'Switzerland of Africa'. In terms of electricity supplies, clean drinking water, clinics, schools and good roads, Rwandans were relatively well provided for, even compared with wealthier neighbouring countries. The hilly terrain was also widely terraced to prevent erosion and maintain soil productivity. In personal relations there was a sense of restraint and a lack of candour that could be interpreted as excessive politeness; much that was unpleasant was left unsaid. We formed close ties with $\mathrm{R}$ wandan friends, some of whom have lived with my family in Belgium 
and elsewhere for more than a decade. Knowing them, and knowing something of what they had to pass through, prompted me to do the research for this article in the first place.

Since the I980s, Rwanda's image has altered drastically, and the country is now considered just one of many failed states in Africa. The country's decline into chaos and conflict is seen as symptomatic of a widespread inability in the continent to sustain imposed economic and political reforms. However, if Rwanda can be said to be an example of a failed state, it is certainly not because the state was weak or ineffectual; if anything, the state became so powerful and efficient that it crushed and overwhelmed Rwandan society completely. Postindependence Rwanda inherited a legacy of close public scrutiny of all spheres of life, continuing the former colonial and monarchical state's ability to control each individual through a network of controls, extending from the apex of the regime to its base at household level. Rwanda illustrates the danger of an efficient and centralised state that 'does not embrace the entire polis', but only 'that part which members of the hegemonic elite think it should embrace' (Gros I996: 460). In this case, the consequences were disastrous for those not included among the full citizenry, who ultimately were targeted and hunted down instead of being protected.

Some accounts of the I 994 genocide have been able to capture its powerfully tragic meaning for Rwandans themselves (Pottier I996). The detailed reports compiled by the London-based NGO, African Rights (I995), for example, have managed to get close to an understanding of the way bonds of inter-personal trust and existing social ties have been almost completely shattered by the experience of genocide. The bonds within civil society were completely broken in the process of organising this genocide and ensuring its completion in record speed and with extreme thoroughness. Imperialist designs of other countries, the historical legacy of inter-group conflict, and the use of psychological manipulation and patterns of social control by a highly authoritarian regime, all have a part to play in any adequate explanation of the genocide. But even all these combined cannot explain what happened to Rwandans themselves when the I994 genocide was planned and implemented. In the words of one author, 'This was where the spirit withered' (Keane r996:4).

A strong sense of secrecy and a false air of normality served to disarm many victims of this genocide. Many Batutsi apparently failed to anticipate the genocide, in spite of mounting evidence that something was being planned, and in spite of periodic killings of unarmed Batutsi 
civilians. Covert actions were an important dimension of the Rwandan regime's close political control, and were especially effective in a highly stratified society, where power differentials had long been taken for granted (Maquet I96r). When the genocide actually started, it took most outsiders, and many Rwandans, by complete surprise. Some prominent extremist politicians and media figures had for some time openly proclaimed that the Batutsi 'had it coming to them', but such references to some awful future event were generally oblique, relying on innuendo, insinuation and humour. Bald statements of intent were rare; and rumours which circulated of planned genocide simply served to further disarm the Batutsi population, by appearing to 'cry wolf'. Had they believed genocide possible, many more Batutsi would have fled the country before April 1994 (Chrétien i 995; Reyntjens i 994). It is important to explain how it was that the genocide remained an 'open secret' until the day it began.

\section{GENOGIDE, ETHNIG ORDER AND 'RAGE'}

We can define genocide as 'a form of one-sided mass killing in which the state or other authority intends to destroy a group, as that group and membership in it are identified by the perpetrator' (Mirkovic i 996: i 97; Palmer i 998). This is close to the United Nations definition also used by such agencies as Médécins sans frontières (Destexhe I 995). A precise definition of genocide has a bearing on the practical question of how to treat those found responsible for planning and implementing the killings. Those who contest genocide may suggest that the killings took place in self-defence, under conditions of civil war. They may agree that those held responsible should be tried for war crimes, but not for the crime of genocide, defined as a crime against humanity under international law (Republic of Rwanda i995: 3I). Those who have adopted this position (who are admittedly very few) reject the use of the term 'genocide' to describe the killings in Rwanda in I994; they include several of the defence lawyers for those accused of genocide by the International Tribunal in Arusha.

The r 994 killings were a genocide precisely because they were planned well before April i994, with predictions of the mass killings that were to take place being made months, and even years, before they actually occurred. Certainly, by January I 994, it was clear to the UN's special envoy for human rights that death lists were being drawn up in preparation for the killing of Batutsi, and the elimination of Bahutu opposition politicians and human rights activists (FIDH I993: 4; 
Reyntjens i 995: 59). From i 992 onwards, members of 'Hutu power' militias were being trained in techniques of hunt and destroy operations, rather than in open armed combat. The regime in power in Rwanda during the early ig9os, along with its regional and international allies, was fully responsible for the genocide of I 994 .

This article will attempt to demonstrate that this genocide represented a last-ditch attempt by an increasingly autocratic and unpopular regime to cling on to state power, whatever the costs for the population at large. In no sense, therefore, was the genocide the result of spontaneous fighting between two competing castes or ethnic groups. The majority of those killed in Rwanda in i 994 were 'the small rural Tutsi from the Hills [who] were in no way different from their Hutu neighbours' (Prunier r 995: 249). Since at least the i950s, average Batutsi and Bahutu have been identical in the language they speak, in their religious beliefs, in their educational and income levels, and in the acres they farm and the number of children they bear. Both in height and looks, differences between Bahutu and Batutsi are not as clear-cut as most historical and anthropological accounts suggest. There is a common notion that it is easy to detect the Bahutu majority and the Batutsi and Batwa minorities on the basis of physical appearance alone. ${ }^{2}$ This is certainly not true. During the genocide, for example, frequent 'mistakes' were reportedly made. In addition, the official definition of a person's ethnic identity was traced exclusively through the male line, an obvious weakness given the difficulty of establishing paternity, compared with maternity. Mixed marriages have been common for centuries, particularly in the south of Rwanda, resulting in many people who resemble neither the physical stereotype of the Tutsi nor of the Hutu.

After independence, those officially classified as Batutsi were subjected to strict quotas in secondary and higher education, and in public employment. For Batutsi women, there was now a strong incentive to marry a Bahutu man, so that one's children might escape such tight controls. Never physically segregated or ghettoised, but living in dispersed housing amongst Bahutu, the Batutsi were made to feel disadvantaged, and constantly reminded that they were erstwhile exploiters, who were lucky to be left in peace to get on with their business. Historically, the Batutsi aristocracy certainly considered themselves inherently superior to the Bahutu, and this notion extended to the poorest Batutsi (a situation which persists even today in neighbouring Burundi). Even before independence and the removal of the monarchy, there was no significant economic difference between 
Bahutu and Batutsi (Prunier i 995: 50). After independence, Rwandan Batutsi came to be confined to a strictly limited sphere of influence, as the Bahutu elite gradually took over the reins of power from the Batutsi monarchy and the Belgian trusteeship power.

From the start of the genocide in April i 994, the international media tended to portray the genocide as resulting from ethnic tensions. Domestically, the official line was that killings were the result of clashes between the Rwandan Patriotic Front (RPF) and the Rwandan Armed Forces (FAR). State propaganda was designed to raise the hackles of the Bahutu population, and, during the early stages of genocide, there was little evidence of overt hostility from Bahutu towards their Batutsi neighbours and relatives. Such hatred and fear was sometimes latent, and could be manipulated, but more commonly it was deliberately created in the context of well-prepared massacres. Among the thousands of ordinary Rwandans who carried out the genocidal killings, most were Bahutu. There was also a tiny number of Batutsi who had changed or disguised their identity. ${ }^{3}$ It should also be acknowledged that many Bahutu tried to protect their fellow Rwandans, Bahutu and Batutsi alike, from being killed. A few succeeded (Mamdani i 996: 23). Neither the RPF invasion in I 990, nor the onset of severe economic crisis in the early ig9os, had provoked spontaneous inter-communal violence between Bahutu and Batutsi in Rwanda. This does suggest that ethnic conflict was quite deliberately engineered in the run-up to the genocide, as attacks on Batutsi increased. By definition, a conscious and deliberate state strategy like genocide cannot be attributed to spontaneous outbursts of mutual antagonisms between ethnic or racial groups. Genocide may well exploit such latent antagonisms, and may create new ones, but it cannot be caused by such divisions.

Both before and after the violence of the I959-62 Revolution, Rwanda had a complex and highly stratified social structure, both in terms of class and status. By the time of independence in I962, an estimated го,оoо Batutsi had been killed and ten times that number had been forced to flee the country. In spite of the overthrow of the Mwami (king) and Tutsi aristocratic rule, most Rwandans' attitudes to authority changed very little after independence. At least until the genocide, individuals continued to demonstrate quite a remarkable degree of internalised social control in relation to their superiors, and domination was considered the order of the day for subordinates (Lemarchand I970). Intense family socialisation, and intrusive state regulations into every sphere of daily life, reinforced this overall 
impression of orderliness and tight social control. This could perhaps help to explain how plans for genocide were kept largely covert. Such secrecy also facilitated widespread participation in the implementation of the genocide. On their own, secrecy and subservience cannot account for the Rwandan state's decision deliberately to direct organised social and political energies at the specific, lethal goal of Batutsi genocide and killing of Bahutu political opponents. Ultimately, by redirecting the population's strong sense of social solidarity and cultural cohesion towards a common 'racial' enemy within the country, the political architects of the I994 genocide were to destroy almost totally any sense of social cohesion within $\mathrm{R}$ wanda.

Research into the Rwandan media during the early ig9os suggests that a 'hard core' within the regime, concentrated in the army, did prepare for genocide. This faction feared for its own survival under any power-sharing arrangement with the RPF, and apparently resolved not to give up without a fight to the death. This provides us with the beginnings of an explanation of the I 994 genocide: as a stateorganised incitement to violence, imposed through terror and ideology, and directed against the minority Batutsi and their perceived allies among the Bahutu. The main organisers were a northern Bahutu elite, united by their senior positions in the army and the top civil service. The initial goal was regime survival, and the means to achieve this was to be as complete as possible elimination of the perceived 'racial' enemy. Since the genocide, a new goal has emerged: to extend Bantu control (for which read Bahutu dominance) throughout eastern central Africa. The goal had become to oust the Hamitic 'race' (for which read the Batutsi) once and for all from their perceived position of dominance in the region. This is perhaps the single most disturbing legacy of the I994 Rwanda genocide: a sharp racialisation of political discourse, unprecedented in the Great Lakes Region since the early era of direct European colonisation.

TANGLED ROOTS

The practice of tracing official Bahutu, Batutsi and Batwa identities through the male line was initially an administrative device introduced for convenience by the Belgians in I933. This method of deriving a single ethnic label for each individual contradicted the complex ways in which social identities were constructed over time throughout the Great Lakes region. Historically, for example, the terms Bahutu and Batutsi were used in relation to each other, and more flexibly than later 
came to be the case. It is reported by Lemarchand (I996: 9-1o), for example, that in pre-colonial Burundi, the same individual could be both Tutsi in relation to clients, and Hutu in relation to patrons. The pre-colonial Rwandan kingdom was divided into more than a dozen clans, each of which included Batutsi, Bahutu and Batwa members. On rare occasions, until the I920s or so, a man born Hutu could be ennobled and lose his Hutu-ness; Bahutu and even Batwa were very occasionally appointed lords of the land. But Batutsi controlled the corresponding positions of lord of the army and lord of the cattle almost exclusively (see Reyntjens i 996: i 82-4; Maquet ig6 I : i 73-85).

As Albert Memmi (I99I : 3 I) reminds us, 'roots can be very tangled things', something not allowed for in the simple and pseudo-tribal legal classification of identity in Rwanda since colonial times. A fairly flexible use of Tutsi, Hutu and Twa identity categories was replaced with a more rigid ethnic or 'racial' interpretation of such identity groups. This hardening of ethnic boundaries resembled the tribalisation of class and caste relations elsewhere in colonial Africa (Wallerstein I99I: I98). Mixed Hutu-Tutsi or Hutu-Twa backgrounds were ignored, although terms such as 'Hutsi' continued to be used informally to indicate the intermediate social identification of mixed Rwandans (and Burundians).

Hardened identity boundaries caused changes in attitudes towards mixed marriages and concubinage, particularly between Bahutu and Batutsi. The subterranean world of inter-group sexual relations started to be more openly and critically discussed for the first time in the runup to the genocide, coming to be regarded as a matter of public concern rather than part of a family's private affairs. During the colonial and pre-colonial eras, concubinage of Hutu women by Tutsi overlords, akin to the European mediaeval droit de seigneur, was practised both in Rwanda and in Burundi. After independence, the Rwandan Hutu political elite tended to choose wealthy Tutsi women as marriage partners and mistresses. This provided the new political elite with useful economic ties, but also reinforced an undercurrent of sexual jealousy and resentment among poorer Bahutu men and women. Sexual resentments were expressed in 'ethnic' terms in the media, and jealousy of Batutsi was fully exploited in the hate campaign conducted during the early i99os. The Tutsi aristocracy's erstwhile proprietorial use of Hutu women was not yet forgiven, and the sin was now seen as compounded by Batutsi women's supposed seduction of Bahutu elite men (Maquet i96r: 77-80; Codere i973). The prevalence of Hutu-Tutsi intermarriage and mixing, far from softening attitudes, 
served as an excuse for indignation and sentimental appeals to the honest Hutu volk not to marry the enemy 'race'.

The notion of two exclusive and incompatible Hutu and Tutsi identities was constructed gradually, by exploiting every possible source of frustration of the Bahutu majority. How such identities came to be perceived as polar opposites, where once they had been based on material relations of unequal but mutual inter-dependence, is an interesting question. The reworking of social identities in Rwanda and Burundi from the early twentieth century appears to be an outstanding example of what Eric Hobsbawm and Terence Ranger ( 1983 ) call the 'invention of tradition'. Lemarchand ( I996: 30) similarly uses the notion of self-fulfilling prophecy to describe the way in which reality in Rwanda and Burundi gradually came to resemble myths of racial incompatibility originating in the colonial period. Myths of racial and ethnic origins can come to be acted upon as if they were true; this does not make such myths any less mythical, but it does give them the power to fashion people's behaviour. This form of power deserves closer scrutiny in attempts to explain the 1994 genocide in Rwanda, and current conflicts in the Great Lakes Region.

As Jean-François Bayart (1993: 56) suggests, it is important not to exaggerate the importance of the ethnic factor. Such identities may be printed on people's papers, or may dominate people's perceptions of a conflict situation, but they cannot in and of themselves be the root cause of conflict or violence; they are the way that political conflicts are expressed. Ideologies that promote ethnic identities as primordial tend to gain prominence when underlying structural schisms latent within a society become apparent in a way that threatens the position of the political power bloc. In line with this broad approach to explaining 'ethnic politics', I will try to show that genocide in Rwanda was caused not by ethnic conflict as such or by external intervention, nor by obedience per se, but by a series of state responses to a deeper structural crisis. What Peter Uvin ( I 997) has termed the structural violence of the state was mobilised in the economic, political and ideological spheres. In the most profound sense, the genocidal project was a reaction to a deep-rooted crisis of state legitimacy in Rwanda. ${ }^{4}$

A historical account of the influence of German and Belgian colonial rule is part of any adequate explanation of the 1994 genocide in Rwanda. Yet to try to establish what 'really happened', and distinguish this from the 'mythical' past, is a quixotic exercise. Mamdani (I996: 8) has expressed this point succinctly: 'much of what passed as historical fact in academic circles has to be considered tentative - if not 
outright fictional - as the post-genocidal sobriety compels a growing number of historians to take seriously the political uses to which their writings have been put'. The outlines of some possible explanations can be highlighted, but sharp disagreement will inevitably continue about how to interpret historical accounts of Rwandan socioeconomic and political structures.

\section{GERMAN AND BELGIAN LEGAGIES}

One much-disputed historical 'fact' is the migration theory of the origins of the Batutsi, Bahutu and Batwa. According to early German accounts, the tall Batutsi monarchs were supposed to have descended from (Bahima) invaders who came from Ethiopia, or the Middle East, and to have set up relations of dominance over the indigenous (Bantu) Bahutu farmers and the Batwa hunter-gatherers. The immigration of Batutsi was thought to have taken place in the twelfth or thirteenth century. According to this historiography, the Batutsi of Rwanda and Burundi (as well as other groups seen as racially related) are not really indigenous Africans at all, as are the 'Bantu' Hutu and 'pygmoid' Twa. In I865, the Nile explorer John Hanning Speke first sought to demonstrate the superiority of the 'noble, aristocratic' kingships of the inter-lacustrine zone over the Bantu peoples around them, over whom they generally ruled (Prunier i 995: I O-I I).

Later missionaries and adventurers continued to concoct fantastical theories of the origins of the Batutsi, also known as 'Hamites', descended from the cursed son of Noah. There were gross exaggerations of the physical disparity in size between Bahutu and the taller Batutsi, with the aristocratic minority invariably being compared with the majority of farmers and servants (for such an account, see Gunther I 955: 672-7). The still partly hunter-gatherer Batwa minority group, composing just I per cent of the population, completed the racialised image of a society stratified in terms of status, occupation, physiology, and supposedly in terms of origin as well. Alternatives to the Hamitic migration theories have been proposed to explain the observable (but often greatly exaggerated) physical differences between the three social groups composing Rwandan society. Walter Rodney (I972: I34-4I), for example, stressed that dietary differences might play a part in creating differences in stature between the aristocracy and the peasantry. Such differences might also reflect the polarisation of a previously fluid and mixed society into a more sharply hierarchical and caste-based set of social structures (see Mamdani i 996). 
During colonial rule, church, school, administration and the army were organised around the assumed racial superiority of the Batutsi. The notion of inherited and immutable inter-racial differences in ability and make-up bolstered what was seen as a pre-colonial 'premise of inequality', on which inter-lacustrine aristocracies had long based their claims to legitimacy (Maquet r96I). European religious and racial value systems thus came to be superimposed on earlier divine interpretations of the earthly social order. The idea of race lent spurious scientific credence to the idea that Hutu and Tutsi identities arose from separate sources, rather than being part of a single social system of class, status and occupation. In the i 920 , the triple offices of land, cattle and army overlord were combined into a single position, which became confined to Batutsi alone (Codere i973: 353; Prunier i995: 45-6). When identity cards were introduced in I933, this created problems, since it was impossible to know for sure who belonged to which 'racial' group. According to one account (which may be apocryphal), Belgian colonial administrators so despaired of being able to distinguish Batutsi from Bahutu, that they introduced a means-tested system of ethnic identification. Any man with more than ten head of cattle was to be permanently classified as Tutsi, and any man with fewer than ten cattle as Hutu or Twa, depending on their profession (Van der Meeren i 996: 253-5; Destexhe I 995: viii). Several sources report this as an account of what happened at that time, yet some Rwandans claim it as just another invented historical 'fact'.

Ultimately, colonial institutions based on racial theories of immutable differences proved subversive of Batutsi and monarchical hegemony. The emerging Bahutu elite came to express its search for a political role in racial terms, and Catholicism gave added impetus to this crystallisation of a sense of group oppression and resentment against the Batutsi en masse. Subservience to Batutsi overlordship had lost any voluntary character it might have had in the pre-colonial era, and had also lost its ethical and moral overtones as traditional religion had been replaced by Catholicism. Early on during Belgian rule, overt rebellion against Batutsi overlordship was rare, since relations of clientship provided some economic security and protection for many Bahutu. By the I 950s, the prevailing system of 'exploitative reciprocity' had become less reciprocal and more overtly exploitative. Rebellion against forced labour, ubuhake, became widespread, especially in Rwanda (Lemarchand i 970). ${ }^{5}$ By i 959, when the 'Revolution' started in Rwanda, clientship ties between Bahutu and Batutsi had been emptied of much of their previous economic and ideological content. 
Not only were Hutu-Tutsi relations more overtly coercive and exploitative than before, but the Batutsi and the Mwami came increasingly to be identified with an unjust 'racial' social order, which was seen as colonial and therefore as no longer acceptable. In economic terms, as Ian Linden (1977: I87) puts it: 'The vast interlocking network of relationships in whose interstices Hutu found protection and rose to power was gone', and had largely been replaced by the Belgian colonial economy, geared to coffee production and cash crops.

The Belgians' desire for administrative and ideological simplicity was to have lasting consequences for generations of people living in the Great Lakes region. Most obviously, ethnic markers on all identity cards made it possible to identify Batutsi and implement quotas, and ultimately to implement selective killings (Bayart i994; Destexhe I 995: 3 I). By introducing Christianity and 'tidying up' Rwandan social groups, Belgian colonial administration cut across mechanisms of social cohesion, including the religious belief system and clan structures. This created a monolithic division between Hutu and Tutsi identities, and started to dissolve the ideological glue of Rwandan monarchical society.

As a new class of educated Bahutu started to demand majority rule and 'racial' self-determination, they were encouraged to do so by a new generation of Belgian officials, clergy and soldiers. An interesting possibility, so far little explored in the literature, is that Hutu-Tutsi relations became a vehicle for inter-Belgian rivalries between Flemish and Walloons at that time (Linden I977; Braeckman I996; Uvin I997). After the Second World War, many more Flemish officials and priests were appointed to the colonial service. Posted to Rwanda, they tended to identify with the Hutu underdogs against the Tutsi rulers, whom they may have equated with the Walloon elite in Belgium, perceived as snobbish and effete. For whatever reasons, a new generation of Belgian officials and clergy emerged after I945 and identified more strongly with the Bahutu cause, possibly because of the projection of Flemish feelings of resentment at Walloon domination onto the (completely different) situation of polarisation in what was then Ruanda-Urundi. ${ }^{6}$ Not surprisingly, this is disputed by some Flemish scholars, notably Filip Reyntjens.

Gradually, the Bahutu elite came to regard itself as the only authentic indigenous leadership of Rwanda, and the Bahutu as the only true 'sons of the soil'. Curiously, this claim of historical legitimacy ignored the prior claims of the minority Batwa, almost certainly the earliest inhabitants of the Great Lakes area. During the years prior to 
independence, the image of the Batutsi had thus been transformed from a proud and noble aristocracy to a lazy, parasitic and cruel pastoral 'race', alien conquerors to boot. The Mwami was deposed shortly before independence in 1962 , and from ig6r to ig62 the Belgian trusteeship authorities oversaw the replacement of half of all Batutsi chiefs by Bahutu chiefs. The negotiated end of Belgian rule took place in 1962 , and to the rising Bahutu elite the Belgians must now have seemed like allies in the fight against Batutsi hegemony. It had become obvious by the late i 950 os that the Belgians were prepared to abandon their erstwhile Batutsi allies to their fate. The coloniser now championed the cause of the 'little man', the Bahutu majority (Lemarchand i970: I 79; Linden 1977: 220-8). Political opportunism and growing fears of Tutsi radicalism and pan-African nationalism no doubt prompted this line. The net result, as Uvin ( 1997: 94-6) argues, was that another tribe, the fourth tribe of the inter-lacustrine area, became the only social group not to suffer from the violence that preceded independence. This was the white tribe, the Bazungu.

At independence, Rwanda's Hutu elite was led by Abbé Kagamé and the future president, Grégoire Kayibanda. The 'Bahutu Manifesto' of February r 957 expressed the Hutu elite's desire to end Tutsi dominance once and for all. This document was fairly moderate, however, since it recognised that poor Tutsi shared many of the problems of poor Hutu; it also included the Twa in its demands for human rights for all Rwandans. However, the Bahutu Manifesto defended the need for racial markers on identity cards, and asked that these be retained after independence as a protective measure (Codere I $\left.973: 35^{-}-\mathrm{I}\right)$.

The idea of a hierarchy of races had far more devastating implications in Rwanda and Burundi than could ever have been imagined by the early European explorers and ethnographers who first propounded such theories (Chrétien 1995: 32 I-30; Prunier i995: 7-II). The supposedly foreign origins of the Batutsi, once used to defend their inherent right to rule, were now being used to justify plans to drive them out of Rwanda. A key hate speech was made in I 992 by a leading Hutu power politician, Leon Mugesera, who heralded the genocide when he said that all Tutsi should be sent 'back home to Ethiopia' where they supposedly came from. Their destination was to be reached 'via Nyaborongo (river) on an express trip' (Chrétien r 995: 56; Article I9 I 995: 38-40). When the genocide did take place just two years later, tens of thousands of Rwandans' dead bodies did float down the Nyaborongo river, almost all of them Tutsi or part 
Tutsi. Most were buried by Ugandans who recovered the bodies on the shores of Lake Victoria (where it is reported that Ugandans refused to touch tilapia fished in the lake for some years afterwards). ${ }^{7}$

\section{PLANNING GENOGIDE AS AN ESGAPE FROM GRISIS}

The combined impact of the end of the Cold War and of structural adjustment policies has been to further marginalise sub-Saharan Africa within the global economy. Before the mid-ig8os, Rwanda's government had managed to avoid becoming heavily indebted. To most observers, it appeared that 'the economy [was] on the whole well managed. The money was stable and levels of inflation, foreign debt and corruption were all low' (Waller i 996:34). More than 9o per cent of the population lived in rural areas, but even for them Rwanda had achieved impressive levels of services, including drinking water, electricity, primary education and basic health care. By the early I 990 os, 70 per cent of the population had access to clean drinking water, there was a good road network in all regions, and local clinics and schools operated in the main towns of each district (Waller i 996:9).

This situation started to deteriorate when coffee prices fell in I 986-7; receipts from coffee sales tumbled from $\mathrm{I} 4$ billion to 5 billion Rwanda francs in a single year (ACR I989:B377; Chossudovsky i997; Prunier I 995: I 23). External debt soon started to accumulate, and this was almost entirely due to unfavourable external conditions rather than domestic mismanagement. Despite this, the solution proposed was no different than for governments that had been blatantly corrupt and incompetent, like those of Zaire or Kenya.

As Rwanda's trade deficit accumulated, existing redistributional and welfare policies came under increasing pressure. These had been based on the construction of social cohesion among Bahutu through the imposition of ethnic quotas, and a high degree of economic control of producers and pricing. President Habyarimana liked to champion the cause of the 'little man'. Although he made a point in his speeches of including both agriculturists and herders in his definition of the little man, he also lambasted parasitic traders and misguided intellectuals who exploited the little man and undermined social cohesion (Newbury I992: I93-2 I9; Van der Meeren I996: 257). Strict ethnic quotas continued to apply both in the civil service and in education, and the army was almost entirely Bahutu. Reading between the lines of such political rhetoric, the economic crisis was being blamed on a conspiracy of traders, merchants and intellectuals, professions in which Batutsi 
tended to specialise. Already, Tutsi economic and professional success was eliciting envy from the Bahutu elite. Until the early i 99os, Batutsi business people were allowed to operate relatively freely in private business and in the professions, but were strictly limited in terms of access to public office or official state employment. An uneasy coexistence had emerged between the political and administrative Bahutu elite and the economic Batutsi elite, but this broke down with the RPF invasion from Uganda in I990, and the resulting panic among the Bahutu political class.

The RPF invasion also coincided with the start of structural adjustment policies. In June i990, the government finally yielded to World Bank/IMF pressure to implement a package of structural adjustment measures. Rwanda's national currency was immediately devalued by two-thirds (Waller i 996:33). There was also famine in the south of the country, and farmers' real incomes, which had already been slashed in I 986-7, were further eroded. Budgetary shortages and high import costs meant that health services could not be maintained, and maternal and infant mortality levels rose sharply (Le Monde, 6 April i 994). In the immediate prelude to the genocide, there was a dramatic increase in malaria, combined with severe food shortages and an influx of refugees from Burundi. All these changes dramatically worsened the lives of most Rwandans.

At the same time, something new was emerging as an indirect result of the RPF invasion: a militarisation of Rwandan state expenditure, and growing corruption among the political elite. The army increased in size from 7,000 troops in 1989 to more than 30,000 by I 994 , and, in i 992, emergency financial assistance provided to the government to pay for essential food and drug imports was reportedly diverted into arms purchases (Lemarchand i 994: 6oo; Chossudovsky i997: i i 8). French military assistance worsened levels of corruption and encouraged further purchases of military hardware at the expense of many basic necessities. There was also a rapid para-militarisation of Rwandan society, with the creation of hundreds of civil defence associations and covert death squads, all dedicated to fighting the RPF and 'their allies' (Human Rights Watch i 994). New forms of army and civilian corruption made an appearance, including drug dealing and money laundering. For example, in the early ig9os, according to Reyntjens (I995: 30-I), both the son of French President François Mitterrand, Jean-Christophe, and Habyarimana's son, Jean Pierre, were found guilty of drug trafficking, but neither was sentenced.

By early i 994, agricultural production was in severe crisis and food 
production had declined. As food imports rose and the currency was devalued, a trade gap emerged, with export revenue covering barely one third of the import bill. Food was in short supply, but with growing demand from the military, beer production increased (EIU I 994: 25; Reyntjens i 993: 70 I). Instead of heeding the critical choices and sharing power with opposition parties, so that funds would be released by the World Bank, extremist politicians and military, as well as some powerful business and media interests, set their faces towards genocide as the only 'final solution' to their problems. The economic impact of genocide was immediately disastrous; killing started in the planting season, with the result that the 1994 harvest was less than half its 1993 level. By June I 994, almost all the cattle in Rwanda were dead (Tardif-Douglin i 996: 268; Nteziliyo i 995: 319-38). Replanting started almost at once on return, but farms were in ruins (Pottier i 996).

The devastating economic consequences of falling commodity prices and IMF and World Bank policies were not confronted, because of feared financial repercussions. Instead the woes of the country were blamed squarely on the RPF and their allies, the Batutsi 'enemy within', who together were charged with full responsibility for Rwanda's woeful condition. As economic and political crisis bit harder, the regime's enemies came to include an ever-widening circle of people, incorporating not only the RPF and all Rwandan Batutsis but eventually all 'moderate' Bahutus, and anyone suspected of supporting the Arusha Accords (Chrétien r995; Guichaoua r995; Article I9 i 996).

Under the terms of the Arusha Accords, progress was to be made on the democratisation of political life. In early i994, an Economist Intelligence Unit report ( I994: 24) emphasised the high cost if the government failed to comply: "while there is a political stalemate, Rwanda cannot access the \$3om due to it under the Structural Adjustment Programme, due to expire on April 23'. The imposition of such rigid political conditionality on Rwanda's government hastened moves towards a violent 'final solution' to the country's severe socioeconomic and political problems. Chossudovsky (i 997: i ig) has pointed to the irresponsibility of imposing such conditions, given the 'likely political and social repercussions of economic shock therapy applied to a country on the brink of civil war'. The Rwandan government's refusal to comply with the requirements of the Arusha Accords was to have devastating consequences. There were moves to include the political opposition parties in an interim government, but no steps were taken to incorporate RPF forces into the army, one of the 
conditions of the peace settlement. At the same time, a deteriorating human rights record, and worsening socioeconomic conditions, fed into the growth of domestic political opposition, and it was becoming more and more obvious that the regime could no longer protect or provide for most Rwandans.

BETWEEN DEMOGRAGY AND THE DEVIL

It may be noted that when democratic political reforms were introduced in I99I, political divisions in Rwanda did not coalesce along ethnic lines. Instead, with the dismantling of the one-party state, long-standing tensions surfaced between northern Bahutu elites and those from the south of the country. Southerners generally resented the dominance of a small group of Bahutu northerners in control of the top echelons of the army and administration, whilst northern Bahutu considered themselves purer ethnically, and historically less subservient to the Batutsi than the predominantly 'mixed' southerners. Quotas applied in terms of ethnic origin, but Bahutu from the south were also discriminated against in access to public services and employment. Rwandans from Gisenyi and Bushiru were generally perceived as a privileged elite in terms of their relations with state institutions (see Map I). This included preferential access to higher education and public sector jobs at a time of shrinking state revenues (Prunier i 995: I 23; Van der Meeren i996: 258).

In this context, a 'small house' (translated as akazu) of senior military and civilian officials emerged, centred on the powerful clan of Agathe, the president's wife. The akazu started to organise itself politically and militarily in the early ig9os. Claiming historical legitimacy from a long line of independent Hutu kingships located in north-west Rwanda, this group had tight control over President Habyarimana's extensive networks of political patronage. By the early I99os, akazu members had come to dominate the most strategic positions both in central ministries and in regional government. The growing dominance of this small group of Bahutu northerners over every sphere of Rwandan life came to be deeply resented as the economic recession deepened, and this led to an upsurge in support for opposition political parties. There was a rewriting of $\mathrm{R}$ wandan history, assisted by the university history professor, Ferdinand Nahimana. His studies of pre-colonial Bahutu kingships in the north-west of Rwanda provided the intellectual respectability and historical legitimacy that the akazu craved, by supporting their claims of Bantu purity (Independent on Sunday 8 January i 995 ; Guichaoua i $995: 6$ го-г 3). ${ }^{8}$ 
Map i RWANDA

In a letter of resignation to the MRND in July I992, Christopher Mfizi (appointed by the RPF as Rwandan ambassador to Paris in August i 994, though soon replaced by a more 'loyal' representative) christened the akazu and their representatives in the army and civil service 'Réseau Zéro'. The reference seems almost deliberately obscure, since Mfizi borrows a term used by Roland Barthes to describe the written word; without this 'Réseau Zéro' nothing could be expressed 
and nothing could be said (Guichaoua i995: 6r 7-20). The regime's determination to remain in power gradually led to the defensive creation of a 'state within a state', centred on control of paramilitary youth organisations, which operated in tandem with the army and other state institutions at national, district and municipal levels. As the paid militias of young men grew, fewer and fewer Rwandan people benefited from the protection and patronage of the Rwandan state. This created a distinct 'crisis of clientelism', comparable to that identified elsewhere in post-colonial Africa (Allen r995; Drame i996).

For the akazu, and especially senior figures in the military, the Arusha Accords' requirement that the RPA (Rwandan Patriotic Army) be incorporated within the Rwandan Armed Forces, and be allocated 40 per cent of all officer posts, was seen as the last straw (Prunier I995: I59-64). This condition was interpreted as openly hostile to the already beleaguered Rwandan regime, in a context in which declining state revenues and job losses raised serious worries about the future economic security of the Bahutu state bourgeoisie. An association of senior military officers, known as AMASASU, violently rejected the Arusha Accord proposals for military integration. This association mainly represented the northern Bahutu officers who dominated higher levels of the military (Reyntjens I995: 58).

A vibrant press emerged in Rwanda almost immediately after state controls were relaxed in I99I. Criticism of clannish northern dominance in political life and the army was expressed publicly for the first time. Increasing problems of corruption in the army and civil service were exposed by journalists, often at considerable personal risk (Newbury I992: 213-I5). The 'Gisenyi boys' responded by banning papers, taking them over, and distributing counter-information. A huge public demonstration took place in Kigali in January I992, calling on President Habyarimana to implement the Arusha Accords. The regime's supporters claimed that the RPF had organised the demonstration, and stated that 'democratisation' was being used as a cover for the restoration of Batutsi hegemony and feudalism (Chretien I 995: 38-55, 258-60). Unless the inyenzi (cockroaches) and their allies were defeated once and for all, the old feudal order could come back to haunt the Rwandan Hutu majority. Interestingly, the term inyenzi is not as negative as it sounds, and was first used by Batutsi exiles in the i 960 s to describe themselves, because of their practice of conducting cross-border raids under cover of darkness.

The myth of an on-going, 'racial' struggle for supremacy was revitalised with a vengeance for election campaigns. Ordinary Bahutus 
who had lived peacefully next to ordinary Batutsis were now expected to realise how dangerous those neighbours could be (African Rights I 996: 9-I5). ${ }^{9}$ During each election campaign, a cultivated climate of fear undermined most peaceful opposition to the regime, all of which came to be falsely equated with tacit support for the RPF. The Rwandan Tutsi and Hutu political opposition were ultimately to pay the price for this suppression of overt inter-Bahutu political confrontation; their death was the price required to ensure the continued dominance of northern Bahutu elites, and to paper over any inter-Hutu

divisions. Religious images of suffering and sacrifice were often invoked in the propaganda around the time of the genocide (Chrétien i995: $32 \mathrm{I})$. Southern Bahutu elites and the poor majority were told again and again that differences of class, region and politics were superficial compared with the supposedly profound differences of 'race', which were said to separate all Bahutu from all Batutsi.

As Randrianja ( I 996: 39) notes, 'the deepening of Africa's economic crisis tends to encourage a sort of cultural fundamentalism, comparable to other religious fundamentalisms'. Rwanda has been no exception. It was argued that for Bahutu to be safe, all Batutsis had to be removed from society, amounting to a form of political and ethnic fundamentalism. This reduced all social conflicts to a two-dimensional power struggle between two races (largely ignoring both Batwa and Bazungu). Although still expressed mainly in a covert fashion, by the early ig9os, a 'final war' between Tutsi and Hutu was being presented to Rwandans and to foreign observers as more or less inevitable. Such extremely intolerant political discourses were hardened further in response to pressures to democratise, and the regime, which was already economically beleaguered, responded by going on the offensive. Lemarchand's (1992: 98) warning that 'the movement towards democracy may contain within itself the seeds of its own undoing' seems prophetic in the case of Rwanda in the early ig9os. Under the terms of the Arusha Accords, a transitional government was due to have been installed in Rwanda on 8 April, the day after the genocide started. The UN mission installed in the country was due to leave on 5 April, the day before President Habyarimana's assassination. It does seem that the genocide was very carefully timed.

\section{BLAMING THE VICTIMS}

Any attempt to defend the indefensible requires a demonstration of the unreasonableness of the enemy, or some kind of evidence that the other side's evil designs justify a decision to pre-emptively harm them first. In 
Norman Cohn's (I980) words, such myths about the enemy can ultimately come to act as a 'warrant for genocide'. 'For injustice to be acceptable evidently it must resemble justice' (Moore i 978: 55). Even the most fundamentalist and exclusionary movements claim to be acting in self-defence. This explains why, so often, 'the party which seeks to take power by instituting and legalising exclusion, expulsion, segregation and [even] extermination, claims to be a victim itself' (Guillaumin r 990:9). The Rwandan political elite used the supposed genocidal schemes of the enemy to transform an unpopular but relatively successful group into scapegoats. On Rwandan Batutsis' heads were heaped all the evils of the colonial era, and all the problems of the years since independence, including the economic and political crises of the rg8os and rg9os. The supposed evil intentions and revanchist designs of the Batutsi enemy, both within and outside Rwanda, were seen as the reason the country was not flourishing.

Under increasing pressure, the akazu elite and their political allies in Rwanda revived and elaborated a conspiracy theory known as the Bahima conspiracy. As early as the r970s, it had been claimed that Burundian Batutsi had elaborated a plan, known as the Simbinaniye/Micombero plot, to kill off enough Hutu to ensure a Batutsi electoral majority (Lemarchand I996: 27-8). Reminiscent of the fabricated Protocols of the Elders of Zion during the early twentieth century, the Bahima conspiracy myth lent a spurious justification to plans for genocide of the Batutsi. It was claimed that Bahutu would be slaughtered, or at least recolonised by the Batutsi, unless drastic action was taken to make such an outcome impossible (Chrétien i995: I 4 I-208; Thibon I 995). The enemy was accused of plotting genocide themselves; wholesale slaughter of all Bahutu was said to be on the cards, unless some drastic preventative measures were taken beforehand. Just as the Nazis had done in Germany before the war, extremists in Rwanda 'started with the fiction of a conspiracy and modelled themselves, more or less consciously, after it' (Cohn i980: I93).

Since the entire Hamitic or Bahima race was seen as being in cahoots, it did not matter to the Rwandan regime that there was no significant evidence for the existence of such a plot. The peaceful, humble and hard-working Bantu race, of which the Bahutu were the proud representatives, had to be defended from the evil designs of the Batutsi minority. This scenario was very effective in removing responsibility from the perpetrators of genocide, and placing responsibility for killings onto the victims, a process that can be described as victim blaming. In other words, this was scapegoating using a 
fictitious plot as a justificatory device. Genocide plans had nothing to do with 'ethnic conflict'; as Peter Uvin ( I 997: i I 2) puts it, 'anti-Tutsi prejudice was a construct of Hutu people [or some Hutu people] and not the objective result of Tutsi behaviour' (see also Destexhe i995: 43).

With the opening up of the press, articles and satirical pieces started to emerge which lent credence to the idea of a Bahima/Tutsi plot to dominate the entire East and Central African region. The birth of the Rwandan nation was equated with the revolutionary overthrow of the monarchy in I959, and all Batutsi were depicted as monarchist revanchists desperate to reverse any gains of the Revolution, and return Hutu people to their subservient role of the past. It was believed that the Tutsi elite were about to fulfil their long-cherished ambition to once again conquer and subjugate the indigenous people of Rwanda, the innocent Bahutu (Chrétien I995: I42, I64-7). This recolonisation would mean the restoration of slavery, and a return to the unquestionable superiority of the Batutsi overlords over the Bahutu majority; in short, a return to the pre-revolutionary past. In this allegorical account of events, the RPF ceased to be a nationalist military force based on Rwandan exiles, with a socialist political orientation. Instead, it was depicted as a royalist army of pastoralist raiders, intent on restoring feudalism across the entire Great Lakes region (Chrétien i 995: 253).

All Tutsi were regarded as objective allies of the RPF, on the grounds that they stood to gain if the Bahima conspiracy succeeded. Thus, so long as all Bahutu acknowledged the existence of the Bahima conspiracy, the Batutsi were conveniently converted into enemies of the Rwandan state and its ethnic majority. Opposition politicians and others who spoke up against the ruling Rwandan regime were implicitly part of the Bahima conspiracy, and were a danger to their fellow countrymen and women. According to such false logic, these people were either insane or enemies of Rwandan independence; in either case they were equated with the RPF.

Sexual competition emerges once again as an interesting undercurrent in such victim blaming strategies. There are unmistakable parallels with the sexual obsession of many brands of religious and racialist fundamentalism, not least with Hitler's own obsession with the sexual capacities and appetites of Jewish men and women (Van der Meeren i 996: 256). The fall from grace in the pre-Tutsi Garden of Eden was explained in terms of seduction, both economic and sexual. The 'Hutu desire to own cattle' was the 'fundamental reason for their 
subjugation', as was the desire to marry Batutsi women (Louis I963: i ıо; also Maquet i96ı; Newbury ig88; Lemarchand ı996: 6). In supremacist propaganda, Batutsis are accused of having bought the Hutu's soul, and the majority population is urged to reject contact with the Batutsi and avoid economic, political or sexual dependence on them.

A key document in the Bahima conspiracy theory is the 'Ten Commandments of the Hutu', first published in the Rwandan Hutu supremacist magazine, Kangura, in I990 (No. 6, December). Sexual politics were one of the main ingredients in this race hate tract. The first three of the ten commandments proscribed sexual relations between the two 'races' and openly accused Batutsi of using 'their' women to enslave elite Bahutu men. These 'wives' were Hamitic Eves in the Bantu garden of Eden, and it became the duty of every Bahutu woman to rescue her husband, brothers and sons from such women's clutches. The majority was called on to cut off all business ties with the minority, an uncomfortable request considering that President Habyarimana himself had previously enjoyed close and comfortable business ties with wealthy Batutsi Rwandans. Another of the ten commandments required 'Bahutu to stop feeling any pity for Batutsi'; it advised them to seek support from all 'fellow Bantu' people in the Great Lakes region for their racial emancipation. According to the final commandment, anyone who did not agree with all the preceding commandments should automatically be regarded as a traitor.

A parallel document is the parallel ' i 7 Rules of the Tutsi', again published by Kangura, this time in 1993 (Guichaoua I 995: 567-9). This is a hate tract of dubious origin, but has been presented by some reputable scholars as evidence of a 'Bahima plot' in the Great Lakes region (Lemarchand I 996 :xvii). On closer inspection, it appears to be a rather opaque hoax. Not only does it call on Tutsi to 'identify all Hutu living nearby', an impossible task in most areas where Bahutu outnumber Batutsi by ten to one. There are also references in this document to 'Uganda' as the Batutsi homeland. This is rather suspect, given that the document was said to originate in Burundi, where Batutsi have few connections or affinities with Uganda. Bahutu supremacists, on the other hand, did see Uganda as the source of the revanchist RPF. Another rule advises all Tutsi to stay where they are and fight to the death. This sounds less like a rule (for which organisation would suggest to its members that they were likely to die?) than like a piece of wishful thinking by 'Hutu power' propagandists. The document also suggests that Tutsi should kill all Bahutu children, 
something the rules would not mention if they were genuine. Indeed, the idea of killing children was first raised by Leon Mugesera in his famous 'Nyaborongo River' speech of 1992 (referred to earlier in this article), when he pointed out that many of the fighters of the RPF had left $\mathrm{R}$ wanda in the ig6os as small children. Had they been killed in I959-62, he argued, they could not have returned to fight again (Article I9 I996: 39-40). All this suggests that the document is a forgery, and may well have been fabricated in order to feed the Bahima conspiracy myth.

According to several sources, fictitious reports were common, both on the radio and in the press. One example was a $\mathrm{R}$ wandan radio report that a human rights organisation based in Nairobi had discovered evidence of an RPF plot to kill prominent Hutu politicians and carry out genocide of all Rwandan Bahutu. The available evidence suggests that this story, and the human rights organisation itself, were complete fabrications (Article ig r996; Destexhe r995). Even so, another prominent Rwanda scholar, Filip Reyntjens ( I 995:62), gives this 'news' item credence, and claims that the RPF did indeed plan to kill off Bahutu intellectuals once they took over state power. Mamdani's warning concerning the extreme care that needs to be taken in the Rwandan case, with the use of this kind of 'evidence', is here worth remembering.

The Rwandan regime and its supporters made use of some sophisticated techniques of disinformation, which seem to have been learned from a close examination of wartime propaganda elsewhere. Fictitious bombings of Kigali were staged and reported (EIU I 994: 22; Mackintosh i 996: 45; Article r 9 I 996: 26). Another uncanny example of this was a story reportedly relayed on Radio Mille Collines during the first month of the genocide, and for which no evidence was ever found. This was an almost exact repeat of a partisan story used in Poland. In this account, a young woman, dressed in white, finds herself alive in a mass open grave, dug by her and her family who have been shot by the RPF (originally by the Allies), and fallen into the pit on top of her. She somehow manages to climb out of the grave, and so shocks the soldiers still gathered around that they do not kill her, but instead ask her to cook for them. Eventually she manages to escape while they are eating and lives to tell the tale (Article I9 I 996:48). It sounds like a central European fairy tale, and was repeated almost word for word in Rwanda during the genocide. This kind of borrowing of propaganda tales needs further investigation, and is an interesting aspect of the preparation and execution of genocide in Rwanda. 
Popular music also became a vehicle for ridiculing Bahutus who did not fall in line with Hutu power extremists, or did not sufficiently hate Batutsis. From time to time, government and militia forces staged fake attacks on Kigali in order create panic among civilians and rally extra support for the militias and the extremist Hutu power party, the CDR (Coalition pour la Défense de la République) (Uvin i 997: i Io-I I). Such deliberate and calculated disinformation helped create the right atmosphere for mass killings, both in the run-up to the r 994 genocide, and during the genocide itself.

Such propaganda also had the desired effect of shifting the blame for every Rwandan problem onto the RPF and the Rwandan Batutsi, presumed to be its allies. Like other minorities transformed into scapegoats, Rwandan Batutsi came to be held responsible not only for economic recession and political unrest, but even for their own victimisation. The RPF enemy were reputed to behave in ways that placed them outside the norm of humanity; they were depicted as depraved beasts, capable of atrocities of all kinds including cannibalism, rape and other forms of deviance (Chrétien i995, for cartoons; Oplinger I990: 257-8; Storr I99I: I24, I37). They were even attributed magical and demonic qualities. In a manner strikingly reminiscent of Nazi images of Jewish people, the Hutu 'power' press dehumanised Rwandans of Tutsi origin to such an extent that they became hostages to the RPF. In the same way, the Jews had been regarded as victims of a hidden war with the international Jewish conspiracy. As had been the case in Nazi Germany, anyone expressing any sympathy with Batutsi was automatically branded a public enemy (Oplinger r990: 223; Cohn i980: 21 2).

\section{AN OPEN SEGRET}

In the run-up to April i 994, although plans for genocide were openly broadcast and written about in the media, a deceptive aura of normality was maintained. The ruling party, the MRND, had changed its initials only slightly in response to the democratisation of political life - from Mouvement Révolutionnaire Nationale pour le Développement to MRND(D), adding et la Démocratie. The militias together with the army organised much of the killing during the genocide. They grew rapidly from i 99 I onwards, starting off innocuously enough as local football clubs for street children, and patriotic associations for unemployed youth to carry out public works (Reyntjens I 995: 57-8). Many militias wore authentic Afro-print uniforms, owing much to the 
authenticité of Mobutu's Zaïre (Chrétien r 995: 237). The young men in these militias were trained in fighting techniques, which glamorised violence and involved much chanting, somewhat reminiscent of Winnie Mandela's fictitious football club in Soweto. The largest of these militia groups was the interahamwe, which literally translated means 'those who help one another' (and not, as some studies suggest, 'we attack together') (Destexhe r 995: 29; Manikas \& Kumar i 996: 68; Human Rights Watch i994: 2). Until preparation for genocide, interahamwe were rural self-help work groups, which operated at the level of local communes. They were much praised by donors and seen as essential to the success of Rwanda's development model (Waller i996: 37). Appearances of continuity could be deceptive, and familiar, comfortable terms were often used euphemistically to disguise the serious intent of those preparing for genocide.

When the radio station RTLM (Radio-Télévision Mille Collines) first went on the air, it appeared a jokey and popular station, broadcasting in Kinyarwanda instead of French, more 'street wise' than official Rwandan radio and close to its listeners. It was reported that the RPF troops also preferred to listen to it rather than to the official RPF radio (Article i9 i 996: 86). Yet RTLM seemed to know what was coming, and reported that 'a little something' was planned for early April. The role of this radio station in urging on the killings, broadcasting names of Tutsi and opposition targets, and reporting the whereabouts of those hiding from militias during the genocide, is now well documented. The killing squads (interahamwe) were thus often able to discover people who were hidden with relatives or neighbours, through reports on the radio (Article i9 ig96: Io I).

Like many people who have to live with hierarchy, Rwandans are expert at euphemistic expressions designed both to convey, and to disguise, their true intention. Dissimulation was a vital element of genocide propaganda, and had the power 'to lay asleep opposition; to surprise; to reserve to a man's self a fair retreat' (Zagorin i 990: 256). According to Clapham ( I998: 209), 'groups who sought a genocidal solution' used the period of the Arusha negotiations to prepare for the genocide, and had no intention of agreeing with the terms of any settlement. Ambiguity was deliberately cultivated during preparation for the genocide, and even during its implementation. Thus the genocide was referred to as a big job, akazi gakomeye, or special work umuganda; killing was also repeatedly referred to as tree felling. Prunier (I 995: I 38, I 42) reports that "chopping up men was "bush clearing" and slaughtering women and children was "pulling out the roots of the 
bad weeds"'. The same kind of powerful metaphorical and euphemistic language had also been used in Rwanda in I959, and during periodic massacres of Bahutu in neighbouring Burundi. The references to agricultural labour were therefore not new. Such imagery had the advantage of being open to double meanings (Lemarchand I996: I $25^{-6}$ ). On the one hand, being coded, such messages served to disguise the horror of what was planned; on the other hand, those addressed were reminded of their duty to obediently take part in this 'special shared work'.

Under Habyarimana's regime, Rwandans' sense of orderly discipline was inculcated through weekly umuganda (collective work) sessions, involving periods of 'animation', including dance, praise for the regime and its leaders, and a great deal of collective chanting and clapping. These rituals were repeated in more macabre mode to prepare ordinary people and militias for the job of killing. Eventual compliance was obtained from many of those initially opposed to the killings through propaganda leaflets, and hate speech on the radio and in villages. Those who killed were also promised rewards, ranging from bottles of beer to the property of the dead (Article r9 r996: 33; Prunier r995: I37-8; African Rights i996).

Throughout the Second Republic, the strict requirement to obey orders had been applied to development activities at the level of each local community, and within each 'cell' of ten households. From April I994, the same requirement was applied with similar thoroughness to achieve a different aim: the rapid elimination of all Batutsi, part-Tutsi and all those who supported them, from Rwanda's body politic. Collective works, such as terracing, wood felling, tree planting, road mending and construction work, had all been based on voluntary labour during the First and Second Republics (Waller i 996: I9-20). The state now required ordinary (Bahutu) citizens to put selfish concerns aside once again, and assist in getting rid once and for all of the Batutsi enemy and its allies. The FAR and militias were soon so busy killing unarmed civilians that by June the RPF was able to overrun the country.

During the genocide itself, orders to kill were issued from the top and passed down; those who refused to kill were almost always killed themselves. The result was the almost total destruction of social bonds and relations of trust, and a situation where "pupils were killed by their teachers, shop owners by their customers, neighbour killed neighbour and husbands killed wives in order to save them from a more terrible death' (Destexhe i 995: 3I). Even young schoolchildren were used to 
help identify the enemy and point them out (African Rights I996). Almost no-one escaped the killers, who could include close relatives and the extended family, as well as neighbours, local officials, soldiers and militia members. Many victims of the genocide appeared to be taken by surprise, and were killed while seeking shelter in churches, mayors' offices and schools. Because the planning of genocide was shrouded in an 'illusion of normality' (Friedlander I997: 6o-I), many Batutsi refused to believe that their Bahutu neighbours and the armed forces would one day come to kill them simply because they were Batutsi.

Rumours of a forthcoming 'apocalypse' were frequent prior to I 994, and preparations by militias were fairly obvious. Yet such dangers may have seemed unbelievable to ordinary Rwandan Batutsi, who were probably more concerned with daily survival than with questions of political ideology. The international community also ignored some early warnings. Grave concerns had been expressed both by the International Federation for Human Rights, and by the UN Special Rapporteur for Rwanda, Degni Segui, prior to the genocide. In January r 994 even General Dallaire, the commander of the UN force in Rwanda, issued a warning (FIDH r 993: 4; Republic of Rwanda I995: 3I-2; Reyntjens I995: 59; Mackintosh i996: I47-8). Unintentionally, there may have been so many warnings that they became rumours, tending to disarm the intended victims of the genocide rather than prepare them for self-defence; perhaps the Batutsi had already heard the little boy cry 'wolf' so many times that they no longer listened. By April I994 it was too late, and the wolf of genocide had started to attack its victims in earnest (Reyntjens calls it 'machinery', I $996: 248)$.

IMPLEMENTING GENOGIDE：OBEDIENGE AND TERROR

The counterpart of Rwandans' much-noted obedience to authority has been what Prunier (1995:3) terms the 'almost monstrous degree of social control' of the Rwandan state over almost every aspect of people's lives. Prior to the genocide, a form of 'chillingly purposeful bureaucratic control' was exercised over the population by governmental authorities (Oplinger i990: 260). Population movements had been minutely controlled since the late ig8os, and under the state of emergency declared in November i99o, permission was needed for anyone to move out of their commune into another area, and curfews were in operation. For decades, peasants had been told exactly when and what to farm, and could be fined if they did not comply with such 
instructions. They were also expected to carry out free labour one day a week (Newbury i 992).

Social conformism has sometimes been explained as a legacy of traditional pre-European Rwandan society, where respect for hierarchy was already firmly entrenched. Internalised inegalitarian notions, requiring constant 'self-surveillance' by subordinate individuals, are also seen as making externalised violence in the society largely unnecessary (Thibon i 995). In Rwanda, respect for authority and the fear of stepping out of line was a marked feature of the postindependence status quo, and was incorporated into the planning and design of community-level developmental activities. That is not to say that there was no room for manoeuvre 'from below' (Pottier i 996). But a sense of discipline and self-sacrifice among the populace, and the honesty and dedication of most state officials, was none the less widely commented on and much admired by outside observers during the i 980 os (Newbury i 992).

Reyntjens ( 1996 : 244-5) saw this tendency for obedient compliance as facilitating the ruthless efficiency of genocide in i994. Since 'the state is present everywhere and every Rwandan is administered... Orders travel fast and well from top to bottom'. The result was a highly efficient machinery of government that enabled the implementation of a complex genocide plan in a short time span, using highly effective propaganda techniques and with a high degree of military preparedness. Deference to authority is certainly not a pathology of particular peoples, but it does have some material basis in the extremely hierarchical social structure which has characterised $\mathrm{R}$ wanda for centuries. Some have suggested that a high degree of social control may be needed because of the high population density and the need to maintain close social relations within a confined area (Waller I996: i 8; Prunier r 995: 3-4). Population density in Rwanda is exceptionally high for Africa, at about 208 people per square kilometre, and between 400 and 800 for arable land, depending on the district (Economist Pocket Africa i 995:20).

When the orders finally came to kill all Batutsi in Rwanda, and those partly Hutu and with mixed relatives, most of those called on complied, sometimes with enthusiasm (Uvin i997: i I2). Of the few heroes who resisted, most did not live to tell the tale (Gourevitch I 997: 44-5 I). In a series of well-known experiments, psychologist Stanley Milgram ( I 974) suggested that respect for authority could lead ordinary people to inflict pain and even kill others without feeling responsibility for their actions (see also Miller i 986: I 79-8I ). During wartime, as in this 
genocide, it can be that for most people 'government authority overrides the usual prohibitions about killing one's fellow men' (Storr i 99 I : i 05). As Erich Fromm ( 1984:6) puts it, 'my obedience makes me part of the power I worship ... I can make no error, since it decides for me'. Even those who masterminded the genocide in Rwanda claimed to be acting in the collective self-defence of the majority (cf. Cohn I980: 25). Initially it proved quite difficult to force people to kill their Batutsi neighbours and family, but threats of violence against those unwilling to kill usually ensured that they did as they were told (African Rights i 996).

Killing started in earnest once international observers (except a small contingent of UNAMIR), and European journalists, businessmen, clergy, diplomats and aid workers had left Rwanda. Local officials were obliged to comply with orders to kill Batutsi, and after 20 April no area was left untouched. When the prefect of the southern district of Butare refused to order Bahutu in his area to kill Batutsi, he was himself killed, and militias from the north took over the area (Prunier r 995: 26 I; Article ig I 996: 57). This put an end to almost two weeks of local resistance to the genocide. Killers were urged on day and night: 'by 5 May, the country must be completely cleansed of Tutsis', said Radio Libre Mille Collines (Destexhe I995: 32). RTLM repeatedly referred to the Simusiga, or hurricane, portraying the genocide as a quasi-natural event which it was futile to resist (Article i9 i996: iоr).

During the genocide itself, physical features such as 'a long nose, long fingers or height (were) considered a sufficient basis for a sentence of death' (African Rights i 996:45). The blurred distinction between the two 'ethnic groups' in terms of appearance, and their overlapping physical characteristics, meant that looks could not be taken as a reliable indicator of the individual's official ethnic identity (Clapham I 998: 197). Identity cards were therefore examined at all checkpoints set up throughout the country during the genocide. Mixed Hutu-Tutsi babies and children were generally killed to prevent them seeking revenge for their parents' death once fully grown, and Bahutu who had married Batutsi partners were sometimes also killed to punish them for marrying the enemy, even if it had been decades earlier. Many Bahutu who had the misfortune to 'look Tutsi' were killed on the basis of appearance alone, and some Batutsi who 'looked Hutu' had forged ID cards and managed to escape death (Mackintosh r996: $3^{8}$ ). Even if ethnic identities had been removed from identity cards, as had been demanded some years earlier by observers, physical appearance and 
people's long memories, as well as municipal records, could have been used to help identify all those who had been targeted for extermination.

INDIFFERENGE AND DENIAL

Of late, there has been much exposure in the media of the failure of the United Nations and the international community to take action to prevent killings once the genocide started (The Guardian 7 December I 998). In April and May r 994, the international community, through the United Nations, was unable and unwilling to prevent a continuation of what was soon understood to be genocide. The United States in particular was preoccupied by its own domestic concerns and initially did not seem to give much thought to the nature of the killings, being wary of any intervention that would embroil it in something even more complex than Somalia. France simply did what it could to prevent English-speaking Africans from coming to power in Rwanda. An increased UNAMIR contingent of 5,500 troops was agreed to in May, but, for administrative reasons, was never sent. France maintained its ties with the Rwandan armed forces and militias even after the killings started. French material interests included arms sales, and rewards for private companies and 'loyal' Africans (The Economist 25 April i 998). On the other hand, President Habyarimana also knew how to play the Anglo-Saxon peril card for all it was worth, and was assisted by the fact that many RPF forces spoke not French but English (Huliaras i 998; Prunier i 995: io3). France was able to persuade other European countries to stay relatively quiet in the run-up to genocide. There was much bluster about sovereignty, and the violence was explained as a civil war, due to the RPF invasion of the country.

Only a few hundred soldiers, mainly from Senegal and Bangladesh, stayed in Rwanda after mid-April, unable to help and forced to watch while the first genocide in Africa's post-independence history unfolded in front of their eyes (Doyle r 994: 99-103). The only other intervention was when France set up Operation Turquoise, a so-called 'safe zone' in the south-west of Rwanda, at best an ambiguous intervention (Clapham i 998: 207). There was also some support from the ailing dictators of Zaire, Kenya and Togo. As one observer commented (Jones I 995: 248), 'there was no armed humanitarian intervention in Rwanda specifically intended to deal with the perpetration of the genocide. There were ... putatively humanitarian interventions prior to the genocide (to help resolve the civil war) and after it (to punish its perpetrators).' 
One reason there was so little international response to advance warnings of genocide was because of international indifference and ignorance about the reality of Rwanda's situation. Those who planned the genocide did so meticulously, indeed coldly, and lambasted the outside world with the received image of the killings as 'tribal'. They were 'clear thinking, determined criminals', rather than raving fanatics (Destexhe I995: I2). The phenomenon of 'massacres by remote control' characterised the genocide period itself, and as Erich Fromm ( $1973: 404)$ reminds us with reference to the Nazi genocide, 'Hitler did not get involved ... He was never present at a murder or an execution.' The architects of the genocide had their intellectuals too, who had read their history books, and were able to present superficially plausible proof that this was indeed an 'inter-ethnic' or 'tribal' conflict, deeply rooted in the history of the Great Lakes region. For the West, it was almost as if genocide was not really happening, only a simulacrum on television.

Withholding information from outsiders, including reporters, academics and other naive foreigners, is often seen as justified, particularly in situations ridden with internal conflicts. In Rwanda, this is known as amalenga (Reyntjens i 995: 7). Accordingly, the truth of genocide plans was simply denied, and messages were employed which were deliberately ambiguous, being understood by supporters and those 'in the know', but confusingly vague to others. 'To those who have no right to know one could adapt one's speech by using language that they would misunderstand through ignorance' (Zagorin i990: 25I). The methods used by architects of the Rwanda genocide were reminiscent of those used by 'negationists' of the Holocaust. 'Verbally attack the victims, deny - even in the face of the clearest evidence - that any physical violence is taking place or has taken place' (Prunier i 995: 24I). The Batutsi were even said to be committing collective suicide. Such techniques were as much for international opinion as for the Rwandan population.

After killing the liberal Bahutu Prime Minister Agathe Uwilingiyimana and other leading opposition figures on 7 April, the interim government broadcast its 'regret' at what it called the tragic killings of these leading politicians (Article i9 i 996: i 37-8; Reyntjens i 995: 75). The akazu seemed to be counting on this form of denial being accepted, presuming, quite realistically, a high level of media ignorance about Rwanda, particularly in the anglophone world. The akazu was assisted in this by an apparent loss of will on the part of the international community and the UN Security Council. The French were allowed to 
present their 'Zone of Peace' to the UN as a humanitarian military intervention, in spite of their record of military assistance to militias and to the Rwandan army prior to May r 994.

Whereas much of the international media (especially in Britain and the United States) had started by treating reports of killings as another example of 'tribal' massacres in Africa, resulting from mutual ethnic hatreds, it soon became apparent that there was rapid, efficient and systematic killing of unarmed civilians. Photographs soon started to emerge of mass graves, of piles of dead left to rot in churches, of bloated corpses floating down the Nyaborongo River, dead bodies strewn by roadsides, not buried and not even covered up. The genocide was soon exposed as fact, and the planned and one-sided nature of the killings lay as exposed as the bodies of the dead. Most journalists and commentators started to understand that there had been 'a well-planned campaign of politically and materially motivated slaughter', which had nothing to do with received stereotypical images of inter-ethnic fighting in Africa, in the Balkans or elsewhere (Keane i996: 30). By May, reports were filtering through into some newspapers in France, the UK and US that gave evidence of genocide and contradicted initial reports of civil war and anarchy. By the end of June, a whole swathe of Rwanda's civilian population, including men, women, children, foetuses (and generations to come), had been wiped out.

The UN Security Council set up an International Tribunal for Crimes against Humanity in November i 994, and the fact of genocide was at last officially recognised. Yet throughout this period, US government employees were reportedly ordered to refrain from using the term 'genocide' in any official pronouncements on Rwanda (Article i9 I996: ir6). Denial is resistant to evidence, and as in Germany during the Nazi era, such denial started before the genocide was over, and even before it began, and has continued now it is (more or less) over. There are still references to the 'civil war' of I 994 by those who find it hard to admit the collective responsibility of the former regime and its supporters for organising the killings on a selective basis (see Gourevitch I997).

Had the genocide of 1994 been passed off as "just another African tribal bloodletting', it would have had profound effects for the study of political change and democratisation in the continent. A fatalism about African politics, already very fashionable in Western European and US military and political circles, would have been reinforced with potentially disastrous consequences for democratisation policies in the continent. There is still a sense of disbelief at the enormity of the 
killings: as many as I million people dead in I oo days. A sense of weariness is obvious among policy makers and journalists, as well as academics, contemplating the events of I994 and the repercussions since. Some hope it can all be explained in fairly simple terms, without controversy or counter-accusation or complex trials in which some are found guilty and others accuse. Unfortunately this is not possible. The indifference of the international community raised all kinds of ethical and practical problems, particularly given the willingness to skirt round the issue of genocide with the government of Rwanda. As Fergal Keane ( 1996 : 30) has put it: 'genocidal killing in Africa diminishes all of us'. It diminished Rwandans' sense of themselves, since ultimately some Rwandans carried out and planned selective killings on a huge scale (Mamdani i 996: i9-23).

\section{EXPLAINING RWANDA THROUGH BURUNDI}

It is quite artificial to consider Bahutu identity without considering Batutsi (and Batwa) identity in tandem. Similarly, it is somewhat artificial to study post-colonial events in Rwanda and Burundi as if they took place in isolation from each other. Only by extending the scope of this article beyond the confines of Rwanda can we hope to have an adequate explanation of how the genocide of I 994 could have come about, and how it could been conceived of in the first place. There are very significant historical and contemporary interconnections and mutual responses in terms of Bahutu-Batutsi inter-group relations. The two neighbouring inter-lacustrine states, roughly the size of Holland and Belgium, have been as intertwined as 'Siamese twins' since at least the start of Belgian trusteeship after World War I. From i 962, when both Rwanda and Burundi became independent, each country's domestic politics has coloured perceptions of sociopolitical conflict in its neighbour (Anacleti r996: 3 I0). Complex relations of inter-dependent reaction and counter-reaction have emerged, and these have contributed to the crystallisation of notions of separate, rather than interdependent, Bahutu and Batutsi identities, a process started during the colonial era.

From i96o until i99o or so, Rwanda and Burundi resembled an 'inverted mirror image' of each other; the Rwandan state was controlled by Bahutu elites, and Burundi was controlled by Batutsi elites. The institutions of each state were administered in such a way as to benefit one social group (or at least its dominant minority). The perceived enemy social group was tightly controlled and even 
persecuted. The persecution of Bahutu in Burundi was thus aggravated by, and in turn used to justify, the persecution of the Batutsi in $\mathrm{R}$ wanda. Such retaliation was also fuelled by refugee movements across the Rwanda-Burundi border, and by lurid tales told by those who fled. When Rwanda had became independent, Batutsi in both Rwanda and Burundi feared a Belgian plot to eliminate them. Bahutu politicians, meanwhile, feared constant cross-border attacks from the disaffected Batutsi exiles. In Burundi, each repression of Batutsi in Rwanda became the pretext for another round of killing of educated Burundian Bahutu. The status quo in Burundi in particular came to be seen as increasingly fragile and in need of defence from its enemies, especially the educated Bahutu. Any adequate account of the r 994 genocide in Rwanda needs to account for the logic of such attacks and counterattacks, which appeared to become progressively more ruthless over the years up to i 994 .

The key event of Burundian politics used to justify the genocide in Rwanda was the killing of the first popularly elected Bahutu president, Melchior Ndadaye, in October i 993, just four months after his election. This assassination was carried out by the army, and reinforced claims that power sharing between Bahutu and Batutsi was impossible; there could be no prospect of trust because Batutsi would not tolerate Bahutu rule (Watson 1994: 26-3I). The fact that Bahutu rule had been the norm in Rwanda since independence was conveniently forgotten and ignored. Certainly, even in the r 99os, the Batutsi regime in Burundi felt unable to accept Bahutu leaders and membership in the army. This had more to do with fears of domination by a Bahutu majority, Rwandan-style, than with pan-Batutsi plans to eliminate Hutu, as the extremists in Rwanda claimed. The killing of Ndadaye marked the start of a series of fatal events and international blunders that resulted in the genocide. It also added to the already rich mythology being developed in order to justify a violent final solution to the problems of Bahutu-Batutsi coexistence in Rwanda in particular, and more generally in the Great Lakes region.

A major expression of the parallel structures was the army; in Burundi the army was entirely controlled by Batutsi, and in Rwanda prior to i994, Bahutu dominated the military structure almost as completely (The Economist 6 July I996, ig October i996). The same was true of the administration and the whole public sector. Educated Bahutu in Burundi were regularly massacred and terrorised, and excluded from state institutions. Rwandan Batutsi were allowed to continue operating in the private sector, but were subject to strict 
quotas once they entered the public sector. Batusti domination of state institutions in Burundi was seen as a legitimation of the quota system in Rwanda (The Economist 27 August i994; Lemarchand 1970). In both cases exclusive 'ownership' of state institutions was based on class as well as on identity labels. Inter-Tutsi elite competition for control of the state in Burundi was matched by inter-Hutu elite competition for the state in Rwanda, but as economic recession and political crisis bit deeper, all conflicts came to be seen as ethnic or 'racial' conflicts.

After the killings of I959 and the Revolution in Rwanda, Batutsi refugees moved into Northern Burundi. They remained among the most reactionary of the Batutsi in the Great Lakes region, in marked contrast, for example, to refugees who fled to Uganda and later joined forces with the NRM (National Resistance Movement) of Yoweri Museveni. Refugees who remained in Burundi were more likely to continue dreaming of the past, and some had hopes of restoring the Batutsi kingships in the region. The coming of more refugees imported a harder notion of Bahutu-Batutsi relations into Burundi; for the first time such relations were portrayed as essentially conflictual rather than consensual or interdependent. There were localised mass killings of Burundian Bahutu in 1972, I988, and I993. In I 993 both Batutsi and Bahutu were killed after the murder of President Ndadaye (Lemarchand I996). Batwa were reportedly ordered by Batutsi to carry out killings of Bahutu (Reyntjens I 995: 55). More than 400,ooo people fled to Rwanda, and up to 300,000 more to neighbouring countries. 'Ethnic cleansing' of Bujumbura began early in i 994. All this set the scene for the genocide plan of the Rwandan regime to be implemented (Lemarchand i 996: 96-ioo, i 22).

By an unhappy coincidence, the killing of Ndadaye coincided with the RPF's second invasion of Rwanda, giving apparent plausibility to the notion of a Bahima (pan-Tutsi) conspiracy to reconquer the entire region, and reimpose the old feudal order in Rwanda. Conspiracy theories continued after the genocide, and became internationalised; not only Pierre Buyoya in Burundi, but also Yoweri Museveni in Uganda and other 'progressive' leaders in the Horn of Africa, were now said to be part of a 'Hamitic plot'. Ethiopia, Eritrea and even the newly-named Democratic Republic of the Congo, were included in this new conspiracy theory. The reversal of the situation in the former Zaire is interesting in this regard. Ominously, the notion of a pan-Hamite brotherhood bent on dominance of the honest Bantu peoples of Africa has become part of a new racialised ideological language in central and eastern Africa (The Observer i 8 May i997). 
Victimisation of Batutsi within Rwanda has consistently been justified as avenging victimisation of Bahutu in neighbouring Burundi. Yet neither country has been willing to openly go to war with the other; indeed their diplomatic relations have generally been fair. The violence of the armed forces has been unleashed against the internal enemy, instead of against a common enemy across the border. In Burundi, the regular killings of Bahutu were also prompted by fears that the Rwandan Revolution would spread south and bring the demographic majority into power in Burundi too (Lemarchand i970). A cycle of what might be described as pre-emptive, internalised retaliation was thus established between the two neighbouring regimes, directed at domestic populations but prompted by reactions to each other's national politics. This cycle accelerated the pace of killings by both regimes during the ig9os and made genocide conceivable (Reyntjens I995:62).

Since i994, the simple mirror image of Rwanda and Burundi no longer applies, and in some ways the two regimes now resemble each other much more closely than at any time since independence. However, in other ways they are very different in their goals and strategies. Whereas the regime in Rwanda is officially opposed to ethnic identification of groups of people and individuals, and has removed ethnic labels from identity cards, the regime in Burundi has done little but target Bahutu since i994. Where there is the least threat of genocide being conducted against Batutsi, there is the most suppression and killing of Bahutu. Where the perpetrators of genocide want to continue their job, the government of Rwanda seeks to promote some measure of civil harmony, justice but also reconciliation (Republic of Rwanda 1995). This is why Burundi has been the main focus of regional peace-making efforts since i994, not Rwanda. Nonetheless killings by both governments continue. The fatal logic according to which only killing today can prevent killing by the 'other side' tomorrow, thus remains unchallenged (Van der Meeren i 996: 263-6). In Burundi, where the Batutsi-dominated army has periodically massacred the Bahutu population since independence, many thousands of Batutsi were murdered for the first time after the assassination of President Ndadaye in I 993. In Rwanda at the same time, as if in order to justify these killings, the extremist RTLM spread the rumour that Rwandan Batutsi danced in the streets at news of Ndadaye's death (Article r9 1996: 90). There was no evidence of this, but it suited the idea that 'all Tutsi were alike', and that they disliked all Bahutu and wished them dead. 
In part, genocide was possible in Rwanda in 1994 because of this interpenetration of perceptions of relations between Batutsi and Bahutu in Burundi and Rwanda. An aid worker reporting on how the effects of the 1994 Rwanda genocide were felt in Burundi put it in stark terms: 'A kind of terror is entering people's minds, and moderates are becoming extremists' (Watson i 994: 3 I). Lemarchand went so far as to warn that Burundi could be the next Rwanda in reverse. 'From all appearances, Burundi has reached yet another turning point in its tortuous path to self-destruction... more and more Hutu will be tempted to join the ranks of extremists ... rabidly anti-Hutu newspapers are circulating, some of which do not hesitate to publish lists of Hutu politicians' (Lemarchand I996: xxii). There are some disturbing parallels between the approach of the Buyoya regime in Burundi, and the former akazu in Rwanda. Both consider themselves representative of their entire stratum or social group, and yet face strong challenges from within their own social group, as well as from the supposed 'ethnic' enemy. Both have proved prepared to sacrifice the interests of almost the entire population in their efforts to stay in power.

After 1994 the situation in Burundi steadily deteriorated to the point where the idea of a genocide in reverse ceased to be glib journalese. In I 996-97 the Burundian army rounded up hundreds of thousands of Hutu into camps, and carried out raids into Tanzania in an effort to isolate Bahutu militias and 'finish them off'. Just as the RPF's (nonracial) notions of $\mathrm{R} w a n d a n$ nationalism were born in exile in Uganda, so the Palipehutu/Parmehutu notions of Burundian and Rwandan identity have been remoulded in the highly politically charged refugee camps of Western Tanzania and Zaire. ${ }^{10}$ Hatreds and fears have continued to be transmitted indirectly from Rwanda to Burundi and back again (Vassall-Adams i 994; Lemarchand I996: го3-4).

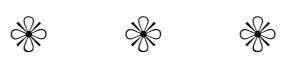

It should by now be clear that there can be no single, simple explanation of the 1994 genocide in Rwanda. A number of possible causes, which need to be included in any satisfactory account of the genocide, have none the less been identified. These include: the colonial ideology of racial division; the economic and political crises of the i 980 s and early i 990 ; the previously very highly organised nature of Rwandan society; and the fragile regional and class base of a political faction determined to hold on to state power at any cost. Other important contributing factors were the use of sophisticated propa- 
ganda techniques, and the escalatory cycle of violence within Rwanda and Burundi. It has been argued that ethnic accounts or a 'racial' explanation of the genocide are untenable. Of course, the politics of ethnic identification was central to implementing genocide plans. Ethnic conflict is usually presumed to be possible only when there is some popular support for separate identities among the majority of the populations concerned. This was not obvious in Rwanda, where ethnic conflict had to be engineered. Logically, carefully planned and wellorganised plans to exterminate a group of people identified solely on the basis of their supposed ethnic, or racial, identity cannot be the same as 'ethnic conflict'; the cause is political and not social. In many ways, we are not much closer to identifying the origins of the political project of genocide than at the start of the article; it is clear that much more in-depth research would be needed in Rwanda (and in Belgium and France) than has been possible here. Clearly a government which was supposed to 'protect the people' ended up doing the opposite (Republic of Rwanda i 995： I3). The present government of Burundi can appear to some to be in danger of a similar bias, although with less dramatic consequences than in Rwanda in r 994 .

A tiny but vocal minority of people seem keen to deny that the $\mathrm{R}$ wanda genocide took place at all. In some cases, they claim the RPF itself was responsible, since it invaded Rwanda, and continues to persecute the Rwandan Bahutu now. A conference organised by Africa Direct in July I997 was entitled: 'Rwanda: the Great Genocide Debate'. According to the conference blurb: 'This conference will examine how the genocide consensus has stifled criticism' of human rights violations and violent attacks by the $\mathrm{R}$ wandan $\mathrm{R} P \mathrm{P}$ regime since I994. Africa Direct has members working in aid organisations, including the former press officer in CAFOD (Catholic Action for Overseas Development), and there have been complaints about their coverage of Rwanda from Rakiya Omaar and Alex de Waal of African Rights, among others (African Rights, personal communications). ${ }^{11}$ Denial is also being used as a legal strategy by defence lawyers at the Arusha trials. Let us assume that there are indeed wrongdoings by the present government of Rwanda, and that the Arusha trials are being conducted in a less than fair manner. Even if these points are conceded, this has nothing to do with whether or not there was genocide in Rwanda in i994. Alleged killers may be brought to trial quite improperly. The RPF may kill unarmed civilians and attack refugee camps (Africa Direct cites attacks on Mugunga camp, for example). But these violations of human rights, if they occur, although they 
deserve exposure, cannot be tied in with the issue of whether or not there was genocide of Batutsi Rwandans in r 994.

The Rwanda genocide of 1994 is now established fact. To question it is criminally irresponsible, and analogous to 'holocaust denial', which is now outlawed in some countries in the EU. Similar legislation might be proposed in the case of the genocide in Rwanda. As the opening quotation from Prunier suggests, distorting the meaning of the genocide of I 994 is tantamount to complicity in the genocide itself, since it dehumanises further those who were targeted and killed. To give an analogy for the sake of clarifying the argument: if the present racialist and militaristic policies of Israel towards its neighbours and Palestinian people were taken as evidence that there was no genocide of Jews during the Second World War, there would be outrage. The same rejection of false logic should also be maintained in the Rwandan case.

Historians, novelists, journalists and filmmakers (among others) continue to examine the legacy of the Nazi Holocaust and to draw lessons from this experience for the present generation. In the same way, we need to continue to examine the implications of the 1994 genocide in Rwanda in order to draw out its lessons for humanity. What happened to the Batutsi in Rwanda is in many senses comparable to what happened to the victims of other historical genocides in the modern period. There are many parallels with the Holocaust, some of which need much more exploration than has been possible here, and could form the basis for interesting doctoral theses in the future. Such issues certainly continue to be deserving of attention, whatever the current geo-political situation in the Great Lakes region. The possibility of truly comparative research on modern genocides is sadly emerging, and can now include an African example of that phenomenon (Palmer I 998). The differences between the genocides of Armenia, Germany and Rwanda are many and obvious. But so too are the parallels, and these differences and parallels are worth investigating in future. In understanding the significance of what is classified as a 'crime against humanity', double standards are unhelpful to scholarship. This is admittedly a very difficult, contentious and highly sensitive field, but genocide needs to be understood, whoever plans it, whoever are the victims, and in whichever part of the world it happens. Although this seems unlikely, if the Batutsi rulers in Burundi were ever to decide on and be able to implement the systematic extermination of the Bahutu population of that country, that too would be genocide. The I 994 genocide in Rwanda would not be a mitigating circumstance for the 
Burundian regime, but neither would it be relativised by any genocide in reverse that might conceivably take place in Burundi.

\section{NOTES}

I. A good example of blaming genocide entirely on the West is Chossudovsky i 994: 24-6, also in Chossudovsky r 997. For other examples, see Prunier 1995: I 57, and Republic of Rwanda 1995. For an excellent account of different perspectives on the impact of colonial theories and history, see Mamdani i 996.

2. The Baktwa and Iguni, two castes of 'pygmies', are potters and hunter-gatherers respectively. They are rarely mentioned at all in recent accounts of events in Rwanda and Burundi, though see, for example, Waller i $996: 4$. The low average income of the Twa compared with either Hutu or Tutsi is noted in Prunier I 995: 40. One of the few pieces of evidence suggesting the Twa suffered heavily prior to and during the genocide is in Bunting I997.

3. One of the most notorious leaders of the militias, Robert Kajuka (sometimes written Kajuga) was himself the son of a Tutsi woman. He was leader of the Impuzamugambi militia of the extremist 'Hutu Power' CDR (Coalition for the Defence of the Republic) and a notoriously ruthless killer. The same pressures to conform led a tiny number of Jews to join the SS for safety, hoping to hide their origins by being 'exemplary' within the organisation.

4. I am grateful to Ernest Wamba dia Wamba, of the Department of History of the University of Dar-es-Salaam and one of the leaders of the Congolese Democratic Movement, for bringing this point home to me. He reminded me of the importance of state crises as an explanation of particular strategies adopted by political elites. In Rwanda, the combination of severe economic crisis with political contestation of the ruling minority, and military vulnerability that led to more harshly divisive state policies from late I980s onwards, culminated in preparation and implementation of genocide in I994. Thanks to Ikaweba Bunting for insights and encouragement (1997).

5. Exploitative reciprocity is the term used by Barrington Moore (1978: 60). On the oversimplification of ethnic boundaries, and the implications of it, see for example Codere 1973: 353, and Prunier i $995: 45^{-6}$

6. The first chapter in Braeckman (1996), for example, suggests that Flemish and Walloon colonial officials and church leaders projected their mutual dislike of each other onto the Batutsi and Bahutu. This idea is criticised on empirical grounds by Filip Reyntjens in a review of Braeckman's book in De Standaard (Antwerp), 2 I November 1996

7. For the pollution of Lake Victoria, see Courrier International, No. I88, 9-1 5.7.I 994, p. 34. In discussion in October 1997, Helen Hakiza, Ugandan national and former MSc student at the Centre for Development Studies, University of Wales Swansea, reported that Ugandans stopped eating tilapia for at least a year after April i994.

8. Nahimana's (I993) study was based on his detailed historiographical studies of the independent Bahutu kingdoms of the north-west of Rwanda, the region from which the akazu originated.

9. African Rights ( I996) provides a detailed and graphic description of how 'revelations' were staged in order to convince the local Bahutu population that their Batutsi neighbours were in fact supporters of the RPF. The report described how the local populations initially united to seek out the interahamwe militias and kill them. Akayesu, who was mayor of a small commune in the south of Rwanda, resisted orders to commit genocide for ten days. He later became the first person to be prosecuted by the International Tribunal in Arusha.

Io. Palipehutu (sometimes spelled Paripehutu) and Parmehutu are two Hutu-based selfpromotion parties or movements based in Burundi and Rwanda respectively. The difference is more in their position than their ideologies. Whereas Parmehutu, allied to the MDR (Mouvement Démocratique Républicain) came to power after the Revolution of I959 in Rwanda, in Burundi Palipehutu has remained an outlawed organisation.

I I. Africa Direct have distributed their materials on the 'Great Genocide debate' at a number of African Studies conferences, including the conference at the Leeds African Studies Unit in I 997, where a version of this paper was originally presented, and where Aidan Campbell was a keynote speaker. Although apparently consisting of only a few people, Africa Direct is part of the Revolutionary Communist Party, which edits Living Marxism. See Aidan Campbell's (1997) strange book, Western Primitivism: African ethnicity, and his review (1996) of Patrick McAllister \& Edwin Wilmsen (eds.), The Politics of Difference: ethnic premises in a world of power. An example of 
the approach objected to by African Rights is to be found in Fiona Foster (1995, I 996); African Rights' co-directors Rakiya Omaar and Alex de Waal discovered that Fiona Foster was in fact Fiona Fox, the press officer of CAFOD (correspondence with the author, October 1997). The March r 996 issue of Living Marxism published a letter of complaint from Efraim Zuroff, Director of the Simon Wiesenthal Center, along with a reply from Mick Hume, the editor of $L M$. An 'Africa Direct Submission to the United Nations Tribunal on Rwanda' explicitly denied that this was holocaust or premeditated genocide, and included statements from the defence lawyers of some of those accused of genocide. One Flemish defence lawyer, Luc de Temmerman, is quoted as saying 'We are convinced that there was no genocide. It was a situation of mass killings in a state of war where everyone was killing their enemies.' Apparently contradicting himself, he adds that 'Everyone was killing but the real victims are the Hutus', Mail \& Guardian, Johannesburg, Saturday, 4 October i 997.

\section{REFERENGES}

ACR. I989. Africa Contemporary Record 2 I.

African Rights. 1995. Rwanda: death, despair and defiance. 2nd edn. London: African Rights.

African Rights. 1996. Witness to Genocide: Jean-Paul Akayesu (First Prosecution by the International Tribunal in Arusha, Tanzania). Issue 4 (September). London: African Rights.

African Rights. 1997. Witness to Genocide: burying the truth in the name of 'human rights': Antoine Sibomana and his supporters. London: African Rights.

Allen, C. I995. 'Understanding African politics', Review of African Political Economy 65: 30 I-20.

Allen, T. \& Kate Hudson. eds. I 996. 'Introduction', War, Ethnicity and the Media. London: South Bank University, I-I3.

Amnesty International. 1995. Amnesty International Newes, August, 26, 8: I-3.

Anacleti, O. 1996. 'The regional response to the Rwandan emergency', Fournal of Refugee Studies 9, 3: 303-I I.

Article 19. 1996. Broadcasting Genocide: censorship, propaganda \& state-sponsored violence in Rwanda 1990-94. October, London: Article i 9.

Bayart, J.-F. 1993. The State in Africa: the politics of the belly. London: Longman.

Bayart, J.-F. I994. Article in La Croix, 2 I-23 May.

Braeckman, C. I996. Terreur Africaine: Burundi, Rwanda, Zaire: les racines de la violence. Paris: Fayard.

Bunting, I. I 997. An Ethnographic Study of the Development Interface: knowledge, power and the phenomenon of the development community. Ph.D. thesis, Centre for Development Studies, University of Wales Swansea.

Campbell, A. 1996. Review of P. McAllister \& E. Wilmsen, eds. The Politics of Difference: ethnic premises in a world of power, in Fournal of Modern African Studies 34, 4.

Campbell, A. 1997. Western Primitivism: African ethnicity. London: Cassell.

Chossudovsky, M. 1994. 'Economic shock therapy', African Agenda I : 2.

Chossudovsky, M. I 997. 'Economic genocide in Rwanda', in Chossudovsky, The Globalisation of Poverty: impacts of the IMF and World Bank reforms. London: Zed/Third World Network, I I I-22. Chretien, J.-P. 1995. Rwanda: les medias du genocide. Paris: Karthala.

Clapham, C. 1996. Africa and the International System: the politics of state survival. Cambridge University Press.

Clapham, C. I998. 'Rwanda: the perils of peacemaking', Fournal of Peace Research 35, 2: I93-2 Io.

Codere, H. I973. The Biography of an African Society, Rwanda 19oo-196o. Sciences Humaines, No. IN8. Tervuren, Belgium: Musée Royal de l'Afrique Centrale.

Cohn, N. 1980. Warrant for Genocide: the myth of the Fewish World Conspiracy and the Protocols of the Elders of Zion. New York: Scholars Press.

Deguine, H. \& R. Menard. i994. 'Are there any journalists left in Rwanda?', Index on Censorship 6: $55^{-9}$.

Destexhe, A. 1995. Rwanda and Genocide in the Twentieth Century. London: Pluto Press.

Doyle, M. I994. 'Rwanda: Captain Mbaye Diagne', Granta 48: 99-103.

Drame, T. i996. 'The crisis of the state', in Ellis, Africa Now, 20I-Io.

Economist Intelligence Unit (EIU). I994. Rwanda Country Report, ist Quarter March. London: Economist Publications.

The Economist Pocket Africa. I995. London: Economist Publications.

Ellis, S., ed. 1996. Africa Now: people, policies and institutions. London: James Currey. 
Federation Internationale des Droits de l'Homme (FIDH). i 993. 'Report of the International Commission of Enquiry into violations of human rights in Ruanda (sic)', Newsletter of the International Federation for Human Rights, (April) : $4^{-5}$.

Foster (Fox), F. I995. 'Massacring the truth in Rwanda', Living Marxism (December) : 35-7.

Foster, F. 1996. 'Rwanda: the great genocide debate', Living Marxism 88 (March): i 5-9.

Friedlander, S. 1997. Nazi Germany and the Jews: the years of persecution 1933-39. London: Weidenfeld \& Nicolson.

Fromm, E. 1973. The Anatomy of Human Destructiveness. London: Cape.

Fromm, E. 1984. On Disobedience and Other Essays. London: Routledge.

Gourevitch, P. 1997. 'Letter from Rwanda: the return', The New Yorker (January): 44-5I.

Gros, J.-G. 1996. 'Towards a taxonomy of failed states in the New World Order: Somalia, Liberia, Rwanda and Haiti', Third World Quarterly I 7, 3: 455-7I.

Guichaoua, A., ed. I995. Les crises politiques au Burundi et au Rwanda (1993-94). Paris: Karthala.

Guillaumin, C. I990. "Race" and discourse', in M. Silverman, ed., Race, Discourse and Power in France. Aldershot: Avebury, $5^{-\mathrm{I} 3}$.

Gunther, J. I955. Inside Africa. London: Hamish Hamilton.

Hammock, J. C. Jr \& J. R. Charny. I996. 'Emergency response as a morality play: the media, relief agencies and the need for capacity building', in Rotberg \& Weiss, From Massacres to Genocide, I I 5-46.

Hobsbawn, E. 1983 . 'Inventing traditions', in Hobsbawm \& T. Ranger, eds., The Invention of Tradition. Cambridge University Press, I-I4.

Hopkins, E. I97 I. 'The Nyabingi cult of Southwestern Uganda', in R. I. Rotberg, ed., Rebellion in Black Africa. Oxford University Press.

Huliaras, A. I998. 'The "anglosaxon conspiracy": French perceptions of the Great Lakes crisis', Journal of Modern African Studies 36, 4: 593-6o9.

Human Rights Watch. I994. 'Arming Rwanda: the arms trade and human rights abuses in the Rwandan war', Human Rights Arms Watch Project, 6, I (January). New York.

Jones, B. D. I995. " Intervention without Borders": humanitarian intervention in Rwanda I 990-94', Millennium 24, 2: 225-49.

Keane, F. 1996. Season of blood: a Rwandan journey. Harmondsworth: Penguin.

Kumar, K., ed. 1996. Rebuilding Societies After Civil War: critical roles for international assistance. Boulder, CO: Lynne Rienner.

Lemarchand, R. I970. Rwanda and Burundi. London: Pall Mall Press.

Lemarchand, R. I992. 'Africa's troubled transitions', Fournal of Democracy 3, 4: 94-105.

Lemarchand, R. I994. 'Managing transition anarchies: Rwanda, Burundi and South Africa in comparative perspective', Fournal of Modern African Studies 32, 4:58 I-604.

Lemarchand, R. i996. Burundi: ethnic conflict and genocide. Ist edn. i 994 . Cambridge University Press.

Linden, I. 1977. Church and Revolution in Rwanda. Manchester: Manchester University Press.

Louis, W. R. 1963, Ruanda-Urundi 1884-1919 Oxford: Clarendon Press.

Mackintosh, A. I996. 'International aid and the media', in Allen \& Hudson, War, Ethnicity and the Media, 37-55.

Mackintosh, A. I 997. 'Rwanda: beyond "ethnic conflict", Development in Practice 7, 4: 464-74.

Mair, L. 1970. Primitive Government: a study of traditional political systems in Eastern Africa. Bloomington, CO: Indiana University Press.

Mamdani, M. 1996. 'From conquest to consent as the basis of state formation: reflections on Rwanda', New Left Review 2 I 6: 3-36.

Manikas, P. M. \& K. Kumar. ı996. 'Protecting human rights in Rwanda', in Kumar, Rebuilding Societies after Civil War, $63^{-8} 3_{3}$.

Maquet, J. J. I96. I. The Premise of Inequality in Rwanda: a study of political relations in a Central African Kingdom. London: Oxford University Press.

Mason, P. i 970. Patterns of Dominance. Oxford University Press/Institute of Race Relations.

Memmi, A. 1972. The Colonizer and the Colonized. London: Souvenir Press.

Memmi, A. 1979. La Dépendance: esquisse pour un portrait du dépendent. Paris: Gallimard.

Memmi, A. r 99 I. 'Mechamisms of oppression, - interview with Albert Memmi', in M. Silverman, ed., Race, Discourse and Power in France. Aldershot: Avebury, 29-39.

Mestrovic, S. I 996. 'Introduction', in Mestrovic, ed., Genocide after Emotion: the postemotional Balkan War. London: Routledge, 5-30.

Milgram, S. i974. Obedience to Authority. New York: Harper \& Row. 
Miller, A. G. I986. The Obedience Experiments: a case study of controversy in social science. Westport, CT: Praeger.

Mirkovic, D. 1996. 'Ethnic conflict and genocide: reflections on ethnic cleansing in the former Yugoslavia', Annals AAPSS 548: i 9 I-99.

Moore, Barrington, Jr. 1978. Injustice: the social bases of obedience and revolt. Basingstoke: Macmillan.

Nahimana, F. I993. Le Rwanda, emergence d'un état, Paris: L'Harmattan.

Newbury, C. I 988 . The Cohesion of Oppression: clientship and ethnicity in Rwanda. New York: Columbia University Press.

Newbury, G. 1992. 'Rwanda: recent debates over governance and rural development', in M. Bratton \& G. Hyden, eds., Governance and Politics in Africa. Boulder, CO: Lynne Rienner, I 93-2 I 9 .

Nirenberg, D. 1996. Communities of Violence: persecution of minorities in the Middle Ages. Princeton, NJ: Princeton University Press.

Nteziliyo, A. i 995. 'L'Agriculture: une priorité dans la reconstruction nationale', in Guichaoua, Les crises politiques au Burundi et au Rwanda, 319-38.

Oplinger, J. I 990. The Politics of Demonology: the European witch craze and the mass production of deviance. London: Associated University Press.

Palmer, A. I998. 'Colonial and modern genocide: explanations and categories', Ethnic and Racial Studies 2I, I: 89-II5.

Pottier, J. I996. 'Agricultural rehabilitation and food insecurity in post-war Rwanda: assessing needs, designing solutions', IDS Bulletin 27, 3: 56-75.

Prunier, G. 1995. The Rwanda Crisis 1959-1994: history of a genocide. London: Hurst.

Randrianja, S. 1996. 'Nationalism, Ethnicity and Democracy', in Ellis, Africa Now, 20-4I.

Republic of Rwanda. I 995. Recommendations of the Conference Held in Kigali from November Ist to 5 th, I995 on "Genocide, Impunity and Accountability: Dialogue for a National and International Response". Kigali: Office of the President.

Reyntjens, F. I 992 'Rwanda', Africa South of the Sahara 1993. London: Europa. 697-709.

Reyntjens, F. 1995. Rwanda: Trois jours qui ont fait basculer l'histoire. Paris: l'Harmattan.

Reyntjens, F. I996. 'Rwanda: genocide and beyond', Fournal of Refugee Studies 9, 3: 240-51.

Rodney, W. 1972. How Europe Underdeveloped Africa. Harare: Zimbabwe Publishing House.

Rotberg, R. I. \& T. G. Weiss, eds. 1996. From Massacres to Genocide: the media, public policy and humanitarian crises. Cambridge, MA: The World Peace Foundation.

Rutinwa, B. 1996. 'Durable solutions: an appraisal of the new proposals for prevention and solution of the refugee crisis in the Great Lakes Region', Fournal of Refugee Studies 9, 3: 3 I 2-25.

Stearns, S. I 994. 'Rwanda: an uneasy peace', Africa Report, 39, I, (January-February): ${ }^{2-4}$.

Storey, A. I 997. 'Non-neutral humanitarianism: NGOs and the Rwanda crisis', Development in Practice, 7, 4: 384-394.

Storr, A. i 991. The Roots of Genocide and Human Cruelty. ist edn i 972. London: Routledge.

Tardif-Douglin, D. I996. 'Rehabilitating household food production after war: the Rwandan experience', in Kumar, Rebuilding Societies after Civil War, 265-85.

Thibon, C. I995. 'Les origines historiques de la violence politique au Burundi', in Guichaoua, Les crises politiques au Burundi et au Rwanda, 5-76.

Uvin, P. I997. 'Prejudice, crisis and genocide in Rwanda', African Studies Review 40, 2: 9I-I I 5.

Van de Meeren, R. i 996. 'Three decades in exile: Rwandan refugees i960-90', Fournal of Refugee Studies 9, 3: 252-67.

Vassall-Adams, G. i994. Rwanda: An Agenda for International Action. Oxford: Oxfam.

Waller, D. i 996. Rwanda: which way now?, Oxfam Country Profile, original i993. Oxford: Oxfam.

Wallerstein, I. I99I. 'Social conflict in post-independence Black Africa: the concepts of race and status-group reconsidered', in E. Balibar \& I. Wallerstein, eds., Race, Nation, Class. London: Verso, 187-203.

Watson, C. I994. 'Burundi: the death of democracy', Africa Report 39, I : 26-3I.

Winter, R. I 994. 'Slaughter in Rwanda: it's more politics than tribalism', Monday Developments I 2 (April): :-9.

Woodhouse, T. 1996. 'Commentary: Negotiating a New Millennium? Prospects for African conflict resolution', Review of African Political Economy 68: 129-37.

Zagorin, P. I990. Ways of Lying: dissimulation, persecution and conformity in early modern Europe. Cambridge, MA: Harvard University Press. 